Board of Governors of the Federal Reserve System

International Finance Discussion Papers

Number 645

September 1999

\title{
THE CONTRIBUTION OF DOMESTIC AND EXTERNAL FACTORS TO LATIN AMERICAN DEVALUATION CRISES: AN EARLY WARNING SYSTEMS APPROACH
}

\author{
Steven B. Kamin and Oliver D. Babson
}

NOTE: International Finance Discussion Papers are preliminary materials circulated to stimulate discussion and critical comment. References in publications to International Finance Discussion Papers (other than an acknowledgment that the writer has had access to unpublished material) should be cleared with the author or authors. Recent IFDPs are available on the Web at www.bog.frb.fed.us. 


\title{
THE CONTRIBUTION OF DOMESTIC AND EXTERNAL FACTORS TO LATIN AMERICAN DEVALUATION CRISES: AN EARLY WARNING SYSTEMS APPROACH
}

\author{
Steven B. Kamin* \\ Oliver D. Babson
}

\begin{abstract}
In this paper we develop a modified "early warning system" (EWS) approach to identifying the roles of domestic and external factors in Latin America's crises. Several probit models of balance-of-payments crises, based on different identified sets of crisis dates, were estimated for six Latin American countries. These models were then used to identify the separate contributions to the probabilities of crisis of domestic and external variables. Our basic finding is that, when the effect of adverse external shocks is removed from the simulated probabilities of devaluation in Latin America, the resultant simulated devaluation probabilities are still high. Taken at face value, these results indicate that devaluation crises in Latin America primarily have been a function of domestic policy and economic imbalances, with exogenous external factors playing only a secondary role. All else equal, this suggests that the adoption of strongly fixed exchange rate regimes in the region may not be too costly in terms of diminished ability to respond to exogenous external shocks.
\end{abstract}

Keywords: devaluations, financial crises

\footnotetext{
*The authors are Assistant Director and Research Assistant, respectively, in the International Finance Division of the Federal Reserve Board. The first author can be reached at Mail Stop 20, Federal Reserve Board, Washington, DC 20551; steven.kamin@frb.gov. The author would like to thank workshop participants in the International Finance Division and in the Inter-American Development Bank for very helpful comments. The views in this paper are solely the responsibility of the authors and should not be interpreted as reflecting the views of the Board of Governors of the Federal Reserve System or of any other person associated with the Federal Reserve System.
} 


\section{Introduction and Summary}

This note is intended to address two related issues regarding Latin America's economic performance. The first of these concerns the root causes of Latin America's macroeconomic volatility. Following the emergence of the Latin American debt crisis in the 1980s, two schools of thought developed to explain the crisis and the dramatic deterioration in economic performance with which it was associated. According to one view, the difficulties in debt repayment, rise in inflation, and slump in output observed in many Latin American economies primarily reflected domestic policy imbalances, including large fiscal deficits, excessive money creation, and overvalued exchange rates. The alternative view placed responsibility for the debt crisis on several adverse external shocks that also were taking place during the early 1980s: a precipitous rise in international real interest rates, a sharp recession among the industrialized economies, and significant declines in commodity export prices. These two views, of course, are not mutually exclusive, but debate continues as to whether domestic or external factors have been more important contributors to Latin America's macroeconomic volatility, both during the 1980s debt crisis and afterward.

The debate over the sources of Latin American macroeconomic volatility, while interesting in its own right, is intimately associated with a second important issue, the choice of appropriate exchange rate regime for Latin American economies. The emergence of the international financial crisis in Asia in 1997, and its subsequent move to Russia and then to Latin America, has sufficed to convince most observers that the fixed but adjustable peg may be unsustainable and excessively vulnerable in a world of high capital mobility. However, fierce debate continues over the relative merits of floating or highly flexible exchange rate systems, on the one hand, and much stronger commitments to fixed exchange rates-including currency boards or the adoption of a foreign currency ("dollarization")-on the other. This debate has been particularly vigorous in Latin America, spurred on, in part, by the expression of interest in dollarization by authorities in Argentina.

Clearly, there are many factors determining whether fixed or flexible exchange rates may be 
more appropriate for Latin America-one of those factors is the source of the region's macroeconomic volatility. ${ }^{1}$ If, as some observers have alleged, Latin America's well-documented history of booms and busts primarily reflects the history of its own domestic policy imbalances-and particularly monetary policy imbalances-than a credible, sustainable commitment to a fixed exchange rate against the dollar or other stable currency may, on net, be beneficial. It would narrow the scope for destabilizing monetary and fiscal policies, while not costing much in terms of the foregone ability to respond to adverse external shocks. Conversely, if Latin America's problems primarily have reflected its vulnerability to negative foreign developments, as other observers have argued, than fixing the exchange rate-either through currency boards or dollarization-is more likely to be costly, on balance. It would prevent an adjustment of the exchange rate in response to adverse external shocks, which might be useful in maintaining economic activity and/or in helping the balance of payments to adjust.

An approach taken by many economists to distinguish between the role of domestic and external factors in Latin America's macroeconomic history has been to estimate a vector-autoregression (VAR) model based on time series of domestic and foreign data. ${ }^{2}$ At the broadest level, this literature has frequently identified certain external variables as significantly affecting the evolution of output in Latin American countries, but often has found domestic factors to have contributed a larger portion of the variance in output. This finding, however, is difficult to interpret, as frequently "own shocks" to output are included as domestic shocks, when in fact these "own shocks" may represent largely unexplained residuals in the models. Hence, the VAR approach has not sufficed to conclusively settle the debate over the sources of volatility in Latin America.

${ }^{1}$ See Hausmann, et. al. (1999) for a comprehensive discussion of the potential benefits that strongly fixed exchange rates could offer for Latin America.

${ }^{2}$ For a recent study along these lines, see Ahmed (1999). Other research in this vein includes Rogers and Wang (1995), Joyce and Kamas (1997), and Hoffmaister and Roldos (1997). 
This may reflect, in part, the fact that the VAR approach is subject to several limitations. First, there often is some ambiguity over what constitutes a "domestic" or an "external" variable. Thus, in some studies, the exchange rate is considered external, while in others it is identified as domestic. Second, the number of variables that can be analyzed simultaneously within a VAR model usually is somewhat limited. Third, and most importantly, output contractions and financial difficulties in Latin America in recent decades usually have been concentrated in severe, non-linear crises where key domestic variables experienced sharp dislocations nearly simultaneously, even though the root causes of the crises may have been building up slowly over time. Given the VAR's focus on identifying shocks, it may be difficult for VAR analyses to appropriately attribute crises to prior accumulations of policy or economic imbalances.

Therefore, as a complement to VAR analysis, in this paper we describe a modified "early warning system" (EWS) approach to identifying the roles of domestic and external factors in Latin America's crises. In recent years, motivated by the desire to be able to predict financial crises such as those that occurred in Mexico, East Asia, Russia, and now Brazil, a substantial literature has emerged focusing on the development of statistical forecasting models for financial crises. ${ }^{3}$ These models typically use, as predictive variables, both domestic factors (such as money growth) and external factors (such as the terms of trade). In principle, to the extent that an EWS reliably tracks the past history of financial crises in a country or region, the relative contribution to these crises of the external and domestic variables included in the EWS can be calculated as well.

The basic approach we took was as follows. First, based on several different methodologies, we identified years during which devaluation crises had occurred in six Latin American countries:

${ }^{3}$ See Kaminky, Reinhart, and Lizondo (1998), Frankel and Rose (1996), Sachs, Tornell, and Velasco (1996), Berg and Patillo (1998), International Monetary Fund (1998), Berg, Borensztein, Milesi-Ferretti and Patillo (1999), Herrera and Garcia (1999), and Glick and Moreno (1999), among others. 
Argentina, Brazil, Chile, Colombia, Mexico, and Venezuela. Second, applying a probit model to pooled annual data for 1981-1998 for the six countries, and to three different sets of identified crises, we estimated the probability of a crisis as a function of a broad set of domestic variables (GDP growth, fiscal deficits, bank loans, M2/reserves, and external debt), variables reflecting external-balance positions (real exchange rates, export growth, and current accounts), and more obviously exogenous "external shock" variables (terms of trade, U.S. real short-term interest rates, and industrial country GDP growth). Third, we used the different models we estimated to simulate the probability of crisis over the 1981-1998 period for the six countries. Finally, we decomposed these probabilities into the parts attributable to domestic factors, external-balance factors, and exogenous external shocks.

Section II below describes the methodology employed in the paper in greater detail. Section III summarizes the results, and Section IV concludes.

\section{Description of Methodology}

\section{1 Crisis-dating systems}

The first step in estimating an EWS is to identify periods of financial crisis. For the most part, the literature on predicting financial crises has taken "crisis" to be synonymous with "speculative attack" or extreme pressure on the exchange rate. In consequence, crisis-dating schemes generally have been based on identifying sufficiently sharp changes either in the exchange rate alone (Frankel and Rose, 1996), weighted averages of exchange rates and reserves (Kaminsky and Reinhart, 1996), or weighted averages of exchange rates, reserves, and interest rates (Eichengreen, Rose, and Wyplosz, 1996).

These approaches to crisis dating raise two concerns. First, since the criteria for identifying crises are somewhat ad hoc-both in terms of the variables chosen to represent exchange rate pressure and, perhaps more importantly, in the designation of how large a change in them constitutes a crisis-it is difficult to have full confidence that any particular dating system has correctly identified the crises in a 
sample. ${ }^{4}$ Second, speculative attacks or devaluation episodes do not always coincide with financial or balance-of-payments crises, as evidenced by the United Kingdom's withdrawal from the ERM. Insofar as the raison d'etre of early warning systems-for many policymakers, if not for foreign exchange market participants-is to predict balance-of-payments and/or financial crises, not merely devaluations per se, it would be useful to know how well devaluation episodes are correlated with financial crisis episodes.

Based on these considerations, in this paper, we developed EWS models based on three different crisis-dating systems. The first of these is that utilized in Kaminsky and Reinhart (1996) and denoted KR in Table 1. It identifies crises as months when a weighted average of nominal exchange rate and reserve changes (weighted by the inverse of their standard deviations) exceeds a threshold of three standard deviations from its mean; to take into account the impact of high inflation on exchange rate changes, this calculation is performed separately for high- and low-inflation periods. Based on the identification of crisis months in the paper, we then-since our model uses annual data-create time series of annual observations for each country, shown in Table 1, with crisis years set to one and non-crisis years set to zero. Because in Kaminsky and Reinhart (1996), crisis dates are identified only through 1996 (check), we have extended this sample through 1998, assuming that their technique would have identified crisis years for Brazil and Colombia in 1998.

As a closely related alternative approach, we created our own crisis-dating system, denoted KB (for Kamin and Babson) in Table 1, based on weighted (by the inverse of their standard deviations)

${ }^{4}$ Edison (1999) compares various related crisis-dating systems, all based on the exchange pressure concept, and notes that even relatively innocuous differences can lead to differences in crisis dates.

${ }^{5}$ One concern with both the KR crisis-dating system and other systems based on measures of exchange-rate pressure is that they rely solely on the official exchange rate, and hence may miss crises signaled by a sharp depreciation of a parallel or black market rate. On the other hand, it is not obvious how the information provided by the official and black market exchange rates might be combined to best indicate movements in exchange-rate pressure, and we leave this to future research to sort out. 
averages of the percentage changes in the real exchange rate and international reserves; declines in these weighted averages in excess of two standard deviations indicate a crisis. ${ }^{6}$ This approach, in principle, may have two advantages compared with the KR system. First, on a conceptual level, it is the depreciation of the real exchange rate rather than the nominal exchange rate that is most likely to be reflective of a balance-of-payments crisis; an inflation-driven depreciation of the nominal exchange rate may not necessarily indicate a speculative attack, and dividing the sample into high- and low-inflation periods may not be adequate to control for this possibility. Second, on a practical level, using the real exchange rate rather than the nominal rate removes the need for the additional-and especially ad hoc-step of dividing the sample into high- and low-inflation periods.

Finally, we thought it might be useful to explore a different approach to crisis-dating that is not based on exchange pressure variables. In principle, a good alternative signal of a balance-of-payments crisis might be a sharp decline in net private capital inflows. Even at an annual periodicity, however, reliable measures of these flows are difficult to obtain. A closely related indicator would be movements in the current account balance, since sharp declines in capital inflows in Latin America generally have required sharp reductions in current account deficits. Current account balances, however, may be excessively affected by movements in other exogenous factors such as the terms of trade or international interest rates, and could lead to mistakes in crisis-dating; for example, a sharp fall in export prices could simultaneously trigger a financial crisis but leave the current account unchanged, as falls in export revenue offset cutbacks in imports.

Based on these considerations, we developed a third crisis-dating system based on movements in annual imports, and denoted $\mathrm{M}$ in Table 1; declines in dollar-value imports exceeding 3/4 of a standard

${ }^{6}$ In order to focus on the effect of changing the definition of the exchange pressure index, but to preserve comparability between the $\mathrm{KR}$ and $\mathrm{KB}$ approaches in other ways, the standard deviations for the KB index were calculated using data only through 1996. 
deviation in any one year are considered to indicate an crisis. (The 3/4 standard deviation threshold level was arrived at through trial and error; larger thresholds led to very few crisis observations, while smaller thresholds led to too many.) The rationale for this system is that during balance-of-payments crises, declines in net capital inflows require either increases in exports, reduction of reserve levels, or reductions of imports to keep the balance of payments in balance. During most Latin American financial crises, neither export responses nor drawdowns in reserves have been sufficient to make up for shortfalls in capital inflows, so that as a result, imports have had to decline sharply, reflecting large exchange rate devaluations and/or declines in domestic demand.

Table 1 compares the crises identified by the three different systems. To a first approximation, the crisis years identified by the three systems tend to cluster together, and there are several crises identified by all three of them: Argentina 1982, 1989; Brazil 1983, 1998; Chile 1982; Colombia 1985; Mexico 1982; Venezuela 1989 and 1994. On the other hand, there is quite a bit of dispersion as well. In the absence of being able to definitively show that one of these systems is superior to the others, these divergences underscore the need to explore the robustness of EWS estimation results to differences in crisis-dating schemes.

\section{II.2 Explanatory variables}

The EWS literature focuses, broadly speaking, on two types of variables that may help forecast future financial crises: (1) variables reflecting the fundamental determinants of a country's financial position (e.g., current account deficits, real exchange rate misalignment, fiscal deficits, debt-service burdens, repayment capacity), and (2) variables reflecting market expectations of a future crisis or the initial effects of an emerging crisis (e.g., real interest rates, external bond spreads, stock market indexes). The purpose of our analysis is to exploit an EWS model in order to assess the relative weight of different groups of fundamental forces-domestic versus external-in the causes of Latin American financial crises. Therefore, we estimate an EWS whose explanatory variables are comprised solely of fundamental 
determinants. The explanatory variables we selected, based on what prior analyses in the literature had suggested might be important, were the following. (A more detailed description of their calculation is provided in Appendix Table 1.)

1. Deviation in real GDP growth from its average in prior three years. Increases in GDP growth are expected to lower the probability of crisis, since they reduce pressures to devalue.

2. Public sector fiscal deficit. Higher deficits are expected to raise the probability of a crisis, since they increase vulnerability to shocks and lower investor confidence.

3. Three-year domestic bank loan growth. High loan growth rates are expected to be associated with possible demand pressures, increases in non-performing loans, and hence higher probabilities of financial crisis.

4. Deviation in real effective exchange rates. High levels of the real effective multilateral exchange rate, relative to its average for 1980-1997, are believed to be associated with unsustainable external positions and hence are expected to raise the probability of a crisis.

5. Deviation in export growth from its average in prior three years. Increases are expected to indicate a diminished need to devalue and hence to lower the probability of a crisis.

6. Current account balance to GDP ratio. Increases in the surplus are expected to indicate a diminished need to devalue and hence to lower the probability of a crisis.

7. Ratio of international reserves to imports. Increases are expected to make a pegged exchange rate more feasible to defend and hence to lower crisis probability.

8. Three-year growth in ratio of M2 to international reserves. High and rising ratios of M2 to reserves are expected to raise crisis probabilities, both because they may be reflective of excessive domestic credit creation, and because they are associated with a low coverage of central bank liabilities by hard currency.

9. Total external debt ratio to GDP. Higher indebtedness is expected to increase vulnerability to a reversal in capital flows and hence to raise the probability of a crisis.

10. Ratio of international reserves to short-term external debt. Lower ratios are assumed to raise vulnerability to liquidity crises and hence raise the probability of a financial crisis.

11. Percent change in country terms of trade. Increases in the terms of trade (export prices over import prices) should strengthen a country's balance-of-payments position and hence reduce the probability of crisis.

12. Percent change in real U.S. 3-month Treasury bill interest rates. Increases in U.S. real interest rates-the industrial country interest rates most likely to affect Latin America--are expected to lead to a decline in capital inflows, a rise in external debt repayment costs, and hence a higher 
probability of crisis.

13. Industrial country GDP growth. Higher foreign growth should strengthen exports and hence reduce the probability of a crisis.

Variables 1 through 3 and 7 through 10 above are considered to be domestic variables, in that they are partially or fully reflective of the country's own policies or other economic conditions.

Variables 11 through 13 are considered to be external-shock variables, since they are almost completely exogenous with respect to the countries themselves. ${ }^{7}$ Finally, variables 4 through 6 -the real exchange rate, export growth, and the current account-to-GDP ratio-occupy a more ambiguous or intermediate category. On the one hand, these variables certainly are affected by domestic economic policies and conditions; on the other hand, they also are affected by international capital flows, commodity prices, movements in the foreign exchange value of the U.S. dollar, and other global conditions. In order to abstract from (largely unanswerable) questions of whether these variables are more domestic or external, we place them in a separate category denoted "external-balance variables".

Based on our identification of crisis years and our selection of explanatory variables, we then estimated a probit model to determine the contribution of the explanatory variables to the probability of a crisis for the Latin American countries in the sample. In this model, the domestic and external-balance variables are entered with a one-year lag; for example, the current account balance in 1981 is used to explain the occurrence of a crisis in 1982. This specification was chosen to correct for likely feedbacks from crises to domestic and external-balance variables. Conversely, external-shock variables enter contemporaneously in the model, reflecting our judgement that they are, for the most part, exogenous with respect to crises or other developments within the country.

Before moving on, we should underscore that there are unavoidable difficulties in categorizing

${ }^{7}$ For a large economy, the terms of trade might be endogenous with respect to that country's exchange rate, but that is less likely to be true in Latin America. 
shocks as domestic or external. It was for this reason that we placed the factors most likely to reflect both domestic and external influences-the real exchange rate, exports, and the current account-in the intermediate category of "external-balance" variables. At the same time, however, even our domestic variables-GDP growth, fiscal performance, bank lending, the money supply, and measures of accumulated debt-are subject to some foreign influence, given the vulnerability of small Latin American economies to the international economy. We believe that by holding constant in the model the contemporaneous effects of the most important external factors likely to influence Latin American countries-the terms of trade, U.S. interest rates, and industrial country growth-we have allowed the estimated coefficients on the domestic variables to primarily reflect the impact of genuinely domestic factors on the probability of devaluation crises. Nevertheless, we acknowledge the possibility that the estimated impact of the domestic variables may also reflect the effect of external variables that are not controlled for, including lags of our external shock variables or other external factors not included in the model.

\section{Analysis of Results}

\section{III.1 Estimation results}

The results of the probit estimation are shown in Tables $2 \mathrm{a}$ and $2 \mathrm{~b}$. Table $2 \mathrm{a}$ presents the results from estimating "broad" models containing all of the explanatory variables described in Section II.2, using as dependent variables the $0-1$ observations defined by the three crisis-dating systems described in Section II.1. Table $2 \mathrm{~b}$ presents the results of estimating "boiled down" models in which the least significant explanatory variables were progressively deleted from the "broad" models, so that only variables assessed as being significantly (or somewhat significantly) related to the probability of a crisis are retained.

For each explanatory variable, we show two calculations. The top calculation is $\mathrm{dProb} / \mathrm{dx}$ : the estimated impact on the probability of devaluation (measured so that 100 percent is shown as "one") 
stemming from a one unit increase in that variable. For example, in the regression shown in Table 2a, Column 1, the $\mathrm{dProb} / \mathrm{dx}$ for the current account/GDP ratio is

-2.46. This means that a one unit increase in the current account surplus-say, from 2 percent of GDP to 3 percent of GDP-leads to roughly a $2 \frac{1}{2} 2$ percentage point decline in the probability of devaluation.

The bottom calculation, within parentheses, for each explanatory variable is a "z" statistic, which has an analogous interpretation to a t-statistic. Hence, the current account/GDP ratio has a z-statistic of 2.12 , indicating it to be significantly different from zero (at about the 3 percent level of significance).

In all three regressions, the results are broadly, but not exactly, consistent with prior expectations. Focusing on Column 1, the application of the model to the Kamin-Babson (KB) crisis dates, all of the explanatory variables are of the expected sign except domestic bank loan growth, export growth, reserves/short-term debt, and industrial country GDP growth. None of those variables are statistically significant, whereas of the nine variables with the expected sign, five are distinguishable from zero at the 5 percent level of significance. Additionally, it is not obvious that the estimated negative sign on domestic loan growth is indeed wrong; Glick and Moreno (1999) point out that if a slowing economy and slowing money demand presage a devaluation, than domestic loan growth might be negatively correlated with devaluation probabilities. In fact, they estimate the contribution of loan growth to the probability of a crisis to be both negative and statistically significant.

The other two equations (based on the Kaminsky-Reinhart crisis-dating system, KR, and on the import-based crisis-dating system, M) are comparable in terms of their proportion of incorrectly signed coefficients. Nevertheless, in both of these equations there are fewer coefficients that are both correctly signed and statistically significant. Additionally, for only eight of the thirteen variables are the signs of the coefficients the same in all three equations. Finally, even when coefficient signs are the same in all of the equations, it is clear that there are substantial differences in the magnitudes of coefficient estimates among the three models. For example, a one percent of GDP rise in the current account surplus is 
estimated to lower the probability of a crisis by 2.5 percentage points in the equation based on the $\mathrm{KB}$ crisis dates, by 1.2 percentage points using the KR crisis dates, and by 4.9 percentage points using the M crisis dates. These considerations underscore the worrisome sensitivity of the results to the methodology used for identifying crises.

However, it is possible that the inclusion of a large number of explanatory variables, many of which are not statistically significant, may introduce a certain amount of noise into the probit estimates. Therefore, for each equation, we sequentially reduced-i.e., "boiled down"-the larger or "broad" initial regressions by deleting the least significant explanatory variables until only significant variables (or, at least, somewhat arbitrarily, the six most significant variables) remained. The resultant "boiled down" regressions, shown in Table $2 \mathrm{~b}$, are similar to each other but by no means are exactly the same. Only two variables show up in all three equations (GDP growth and the terms of trade) while four variables show up in two of the three equations (the real exchange rate, the current account balance, M2/reserves growth, and the fiscal deficit). In all cases where a coefficient appears in more than one regression, the sign of the coefficient is the same across equations. Again, there are important differences in coefficient magnitudes across equations for those variables appearing in more than one equation, in part reflecting the fact that coefficient magnitudes generally are unchanged in moving from the broad to the boileddown regressions. Additionally, the explanatory power of the variables differs substantially across equations; the Pseudo $\mathrm{R}^{2}$ ranges from .375 for the $\mathrm{M}$ equation to .325 for the KB equation and only .227 for the KR equation.

Finally, it is worth noting that of the three external factors commonly cited as being important determinants of macroeconomic outcomes in Latin America-the terms of trade, the level of international interest rates, and industrial country GDP growth-only the terms of trade appear consistently to be correlated with Latin American crises.

\section{III.2 Simulation results}


Based on the probit models shown in Tables $2 \mathrm{a}$ and $2 \mathrm{~b}$, we simulated the probability of $\mathrm{a}$ devaluation crisis for every year of the 1981-98 period for all six of the Latin American countries being studied. These simulated probabilities are represented by the solid lines in Charts 1a-f and 2a-f, and are denoted "All factors" to indicate that they reflect the estimated contributions of all the explanatory variables in the models. Charts 1a-f show the simulated results based on the broad equations, using all three crisis-dating systems, while Charts $2 \mathrm{a}-\mathrm{f}$ present analogous simulations based on the boiled-down equations. The vertical lines in the charts denote years when devaluation crises are identified to have actually occurred, based on the indicated crisis-dating system.

As indicated in the charts, the probit models do a reasonably good job of tracking devaluation crises in the Latin American countries, even taking into account that these are in-sample simulations. Regardless of the equation, the estimated probability of devaluation tends to rise during crisis years and decline in non-crisis years, providing some reassurance that the model is reliably correlating devaluation crises with its determinants.

Additionally, some hope that our results may be robust is raised by the fact that for any given country, the crisis probabilities simulated using the different models appear to move more or less together, notwithstanding the different crisis dates used to estimate the models and the resultant differences in coefficient estimates. It is interesting to note that in cases where simulated spikes in the probability of a crisis do not coincide with an actual crisis as identified by one crisis-dating system, they may coincide with a crisis as identified by another crisis-dating system. In Chart 1a, for example, the simulated probability of devaluation using the Kamin-Babson model spikes to over 60 percent in 1986; while the Kamin-Babson crisis-dating scheme does not list 1986 as a crisis year, the Kaminsky-Reinhart system does.

Returning to the central motivation for this paper, a key question in the issue of the appropriate exchange rate regime for Latin America is the extent to which devaluation crises in Latin America have 
reflected domestic factors, on the one hand, or external shocks, on the other. In order to address this issue, for all our models, we first re-simulated the probabilities of devaluation, leaving the domestic and external-balance explanatory variables at their actual values, but replacing each of the external-shock variables-terms of trade changes, real interest rate changes, and industrial country GDP growth-with their average value over the $1981-98$ period. ${ }^{8}$ The results of this simulation are shown as the shortdashed lines of Charts 1a-f through 2a-f, denoted "Domestic and external balance factors". They can be interpreted as the contribution of domestic and external-balance factors alone to the probability of devaluation, insofar as external-shock variables would not be expected to contribute to devaluation crises provided they remain at their average levels (calculated over two decades).

For the most part, and regardless of which model is used, the short-dashed lines in the charts are not far below the solid lines during crisis years. That is, the devaluation probabilities estimated by the probit model are not much lower when only the contributions of domestic and external-balance variables are considered than when external shocks are incorporated as well.

These results represent prima facie evidence that external shocks have not been very important sources of financial and macroeconomic volatility in Latin America compared with domestic and external-balance factors. However, as noted above, the external-balance factors included in the model-the real exchange rate, export growth, and the current account-may themselves be highly affected by international conditions. Therefore, in order to establish the robustness of our results, we performed another simulation-denoted "Domestic only"-in which both the external-shock variables and the

${ }^{8}$ Glick and Moreno (1999) perform a conceptually similar experiment using their probit model of crises, examining the contribution of three variables-domestic credit growth, foreign reserves, and the real exchange rate-to the probability of crisis for several Asian and Latin American countries during the period of mid-1995 to mid-1997. For Thailand, the only country for which the model predicts a very strong increase in the probability of devaluation over the period, the increase is primarily attributable to falloffs in reserves, with real exchange rate appreciation also contributing, but to a minor extent. 
external-balance variables were set to their mean levels, so that estimated movements in crisis

probabilities reflected movements in domestic variables alone. As may be seen in Charts 1a-1f and 2a-2f, in some countries, such as Argentina and Brazil, domestic factors alone still account for most of the estimated crisis probabilities, but the picture is somewhat murkier for other countries.

In order to make more sense of these results, they are summarized in Table 3. Column 1 indicates, for each country and based on the broad models for each of the three different crisis-dating systems, the average simulated probability of crisis across all of the crises identified for that country. ${ }^{9}$ Column 2 shows the average contributions of domestic factors alone to the estimated probability of crisis for those same crisis years, once the effect of external-balance and external-shock variables are removed. Column 3 shows the average contributions of external-balance factors to crisis probabilities during those years when crises were identified, while Column 4 shows the average contributions of the external-shock variables.

Table 3 confirms what already is apparent in Charts 1a-f and 2a-f: external-shock variables are estimated to have contributed little to the simulated probability of devaluation crises among Latin American countries. ${ }^{10}$ Therefore, it would appear, based on these results, that devaluation crises in Latin America primarily have been a function of domestic policy and economic imbalances. Moreover, these results are not much altered if the external-balance variables are considered to be more reflective of external shocks than of domestic conditions. For each of the three models, the contribution of domestic factors-averaged across the six countries-exceeds the combined contributions of the external-balance and the external-shock variables to the probability of crisis.

${ }^{9}$ The simulations for the broad and boiled-down models were similar enough that we did not feel it necessary to present analogous results for the boiled-down models.

${ }^{10}$ The negative numbers in Column 3 for certain countries and certain models indicate that in those cases, external shocks are believed to have reduced, not increased, the probabilities of a crisis. 


\section{Conclusion}

In this paper we develop a modified "early warning system" (EWS) approach to identifying the roles of domestic and external factors in Latin America's crises. Several probit models of balance-ofpayments crises, based on different identified sets of crisis dates, were estimated for six Latin American countries, using both domestic and external explanatory variables. These models were then used to simulate the probability of crisis over the 1981-1998 period. Finally, we re-simulated the models in order to identify the separate contributions to the probabilities of crisis of domestic, external-balance, and external-shock variables.

Our basic finding is that, when the effect of adverse external shocks is removed from the simulated probabilities of devaluation in Latin America, the resultant simulated devaluation probabilities are not much lower than those which incorporate all adverse shocks, both domestic and external. That is, most of the contribution to the model's estimates of devaluation probabilities appears to be coming from the domestic variables in the model. This is true, regardless of which crisis-dating methodology we employ, and whether we use models employing a broad range of explanatory variables or only those that are most statistically significant. Even if the external-balance variables in the model-the real exchange rate, export growth, and the current account balance-are also considered primarily to reflect external rather than domestic conditions, the remaining domestic variables still are estimated to have accounted for most of the estimated probability of crisis in Latin America.

Taken at face value, these results indicate that devaluation crises in Latin America primarily have been a function of domestic policy and economic imbalances, with exogenous external factors playing only a secondary role. This, in turn, suggests that, all else equal, a strong form of fixed exchange rates (such as a currency board or dollarization) might on balance be a positive option for the region. First, it might narrow the scope for destabilizing domestic macroeconomic policies, or more importantly, convince investors that this scope has been narrowed. Second, given the limited importance of 
exogenous external shocks in the past, the cost of giving up the ability to respond to such shocks in the future might not be too great.

However, a number of important qualifications to these results are in order. First, these econometric results are very preliminary, and more broadly, the development of empirical models to predict financial crises is still at an early stage. Therefore, considerable more work will be required to assess the robustness of our results to different specifications.

Second, as noted earlier, the domestic variables in the model-GDP growth, fiscal performance, monetary growth, and accumulated debt-may be subject to influence by external developments. By conducting the experiment in which even the external-balance variables (which reflect a mix of both domestic and external influences) are considered to be wholly external, thereby biasing downward the estimated contribution of domestic factors, we hope to have offset to some degree the unavoidable endogeneity of domestic factors with respect to external shocks. Nevertheless, the contribution of domestic factors to crises may still be somewhat lower, and the contribution of external factors somewhat higher, than estimated in our paper.

Third, adverse external shocks are not the only developments that, ideally, would elicit a depreciation of the exchange rate in order to moderate declines in output. A decline in export sector productivity, or an exogenous increase in demand for imports, should also lead to a lower exchange rate. Hence, even if domestic factors are shown to have been the most important cause of Latin American devaluations, these factors could have reflected real as well as monetary shocks, and hence may not constitute a strong rationale for giving up exchange rate flexibility.

Fourth, and perhaps most importantly, even if domestic monetary policy shocks have been the primary culprit for macroeconomic volatility in Latin America in the past, it is not clear that they remain the primary culprit looking forward. It is well known that the region has made considerable progress toward structural reform and more prudent macroeconomic policy in the past decade. This is reflected in 
the downward trend in the devaluation probabilities that we estimated for most of the countries in the region. In consequence, Latin American countries may be less in need of the macroeconomic discipline provided by strongly fixed exchange rates than was likely the case in the 1980s; the net costs of strongly fixed exchange rate regimes may accordingly be greater than in the 1980s as well. 


\section{REFERENCES}

Ahmed, Shaghil (1999), "Sources of Economic Fluctuations in Latin America: The Role of External versus Domestic Factors and its Implications for Dollarization," Federal Reserve Board, mimeo, April.

Berg, Andrew and Catherine Patillo (1998), "Are Currency Crises Predictable? A Test, " International Monetary Fund Working Paper 98/154, November.

Berg, Andrew, Eduardo Borensztein, Gian Maria Milesi-Ferretti, and Catherine Patillo (1999), "Anticipating Balance of Payments Crises: The Role of Early Warning Systems," IMF Occasional Paper, forthcoming.

Edison, Hali (1999), "Do Indicators of Financial Crises Work? An Evaluation of an Early Warning System," Federal Reserve Board, mimeo.

Eichengreen, Barry, Andrew Rose, and Charles Wyplosz (1995), "Exchange Market Mayhem: The Antecedents and Aftermath of Speculative Attacks," Economic Policy, 21, October, 249312.

Frankel, Jeffrey and Andrew Rose (1996), "Currency Crashes in Emerging Markets. An Empirical Treatment,” Journal of International Economics, 41, November, 351-366.

Glick, Reuven and Ramon Moreno (1999), "Money and Credit, Competitiveness, and Currency Crises in Asia and Latin America," Federal Reserve Bank of San Francisco Center for Pacific Basin Working Paper No. PB99-01, March.

Hausmann, Ricardo, Michael Gavin, Carmen Pages-Serra, and Ernesto Stein (1999), "Financial Turmoil and the Choice of Exchange Rate Regime", Inter-American Development Bank, Office of the Chief Economist, mimeo.

Herrera, Santiago and Conrado Garcia (1999), "A User's Guide to an Early Warning System of Macroeconomic Vulnerability for LAC Countries," The World Bank, mimeo.

Hoffmaister, Alexander W. and Jorge E. Roldos (1997), “Are Business Cycles Different in Asia and Latin America?" International Monetary Fund, mimeo.

International Monetary Fund (1998), "Chapter IV. Financial Crises: Characteristics and Indicators of Vulnerability," in World Economic Outlook, Washington D.C., May.

Joyce, Joseph and Linda Kamas (1997), "The Relative Importance of Foreign and Domestic Shocks to Output and Prices in Mexico and Colombia," Weltwirtschaftliches Archiv,...

Kaminsky, Graciela Saul Lizondo, and Carmen Reinhart (1998), “Leading Indicators of Currency 
Crises,” International Monetary Fund Staff Papers, 45, No. 1, March,1-48.

Kaminsky, Graciela and Carmen Reinhart (1996), "The Twin Crises: The Causes of Banking and Balance-of-Payments Problems," Board of Governors of the Federal Reserve System, International Finance Discussion Paper No. 544, March.

Rogers, John H. and Ping Wang (1995), "Output, Inflation and Stabilization in a Small Open Economy: Evidence from Mexico,” Journal of Development Economics 46 (2), 271-293.

Sachs, Jeffry, Aaron Tornell, and Andres Velasco (1996), "Financial Crises in Emerging Markets. The Lessons from 1995," Brookings Papers on Economic Activity, 1:147-215. 


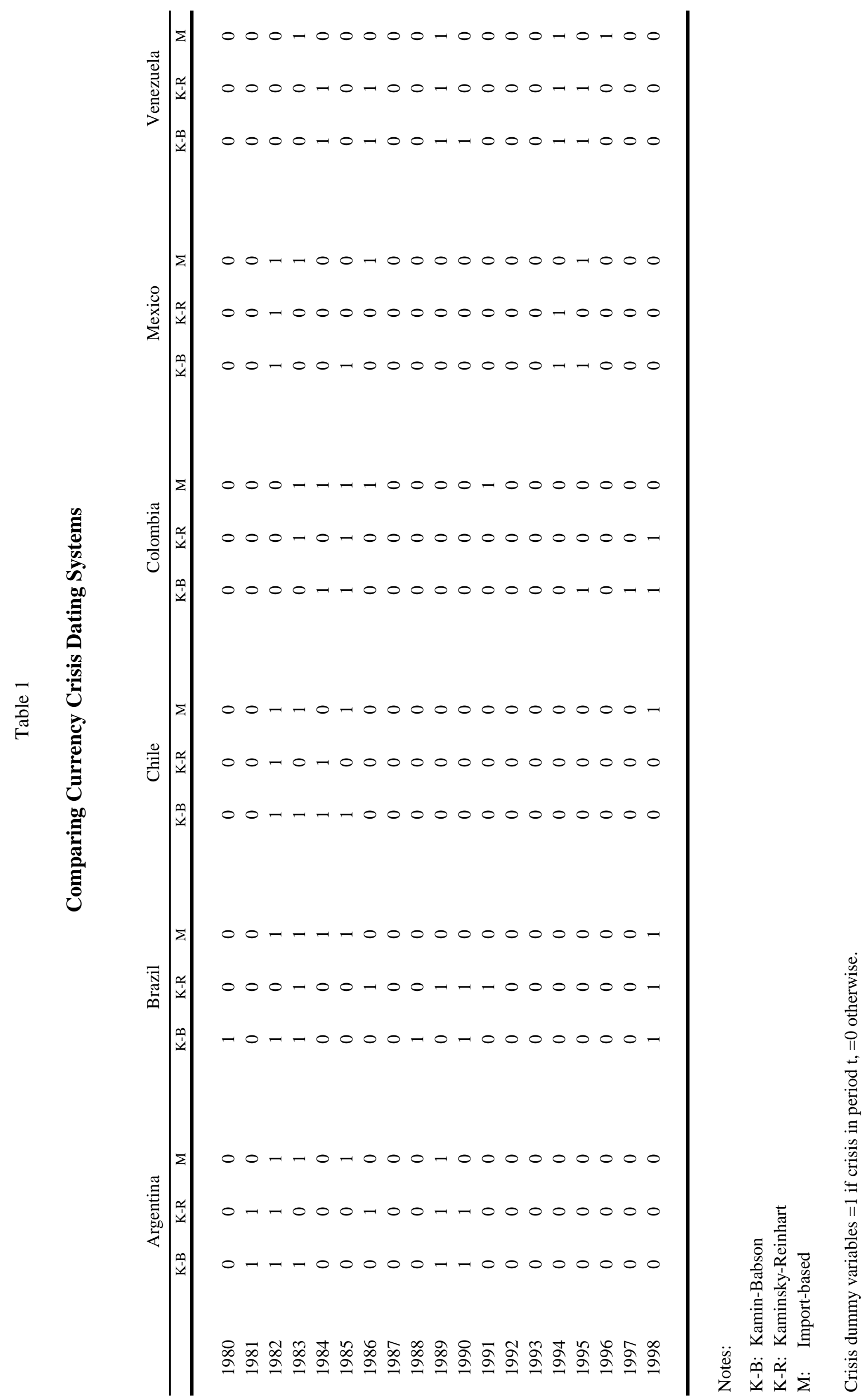




\section{Broad Regression Results}

Dependent Variable: Crisis Dummy

\begin{tabular}{|c|c|c|c|}
\hline & Kamin-Babson & Kaminsky-Reinhart & Import-based \\
\hline $\mathrm{Chi}^{2}$ & 45.86 & 29.65 & 47.24 \\
\hline Pseudo $\mathrm{R}^{2}$ & 0.3649 & 0.2651 & 0.3962 \\
\hline Real GDP growth (L) & $\begin{array}{c}-3.04 \\
(-2.94)\end{array}$ & $\begin{array}{c}-1.24 \\
(-1.76)\end{array}$ & $\begin{array}{c}-1.20 \\
(-1.49)\end{array}$ \\
\hline Fiscal deficit/GDP (L) & $\begin{array}{c}0.81 \\
(0.90)\end{array}$ & $\begin{array}{c}1.12 \\
(1.41)\end{array}$ & $\begin{array}{c}2.15 \\
(2.32)\end{array}$ \\
\hline Loans/GDP (L) & $\begin{array}{c}-0.11 \\
(-1.10)\end{array}$ & $\begin{array}{c}-0.02 \\
(-0.29)\end{array}$ & $\begin{array}{c}-0.24 \\
(-2.17)\end{array}$ \\
\hline Real exchange rate (L) & $\begin{array}{c}0.53 \\
(2.48)\end{array}$ & $\begin{array}{c}0.22 \\
(1.23)\end{array}$ & $\begin{array}{c}0.05 \\
(0.24)\end{array}$ \\
\hline Export growth (L) & $\begin{array}{c}0.25 \\
(1.18)\end{array}$ & $\begin{array}{c}0.14 \\
(0.76)\end{array}$ & $\begin{array}{c}0.02 \\
(0.09)\end{array}$ \\
\hline Current account/GDP (L) & $\begin{array}{c}-2.46 \\
(-2.12)\end{array}$ & $\begin{array}{c}-1.17 \\
(-1.12)\end{array}$ & $\begin{array}{c}-4.87 \\
(-3.15)\end{array}$ \\
\hline International reserves/Imports (L) & $\begin{array}{c}-0.03 \\
(-0.16)\end{array}$ & $\begin{array}{c}0.25 \\
(1.41)\end{array}$ & $\begin{array}{c}-0.18 \\
(-0.95)\end{array}$ \\
\hline M2/Reserves (L) & $\begin{array}{c}0.16 \\
(2.40)\end{array}$ & $\begin{array}{c}0.06 \\
(1.01)\end{array}$ & $\begin{array}{c}0.10 \\
(1.53)\end{array}$ \\
\hline Total external debt/GDP (L) & $\begin{array}{c}0.36 \\
(1.58)\end{array}$ & $\begin{array}{c}0.06 \\
(0.31)\end{array}$ & $\begin{array}{c}-0.22 \\
(-0.90)\end{array}$ \\
\hline Reserves/Short-term debt (L) & $\begin{array}{c}0.02 \\
(0.21)\end{array}$ & $\begin{array}{c}-0.15 \\
(-1.65)\end{array}$ & $\begin{array}{c}0.10 \\
(1.18)\end{array}$ \\
\hline Change in terms of trade & $\begin{array}{c}-0.80 \\
(-1.92)\end{array}$ & $\begin{array}{c}-0.60 \\
(-1.73)\end{array}$ & $\begin{array}{c}-0.74 \\
(-1.68)\end{array}$ \\
\hline Change in U.S. real interest rate & $\begin{array}{c}0.03 \\
(1.21)\end{array}$ & $\begin{array}{c}0.02 \\
(1.40)\end{array}$ & $\begin{array}{c}-0.01 \\
(-0.25)\end{array}$ \\
\hline Industrial country GDP growth & $\begin{array}{c}0.15 \\
(0.04)\end{array}$ & $\begin{array}{l}-1.45 \\
(-0.42)\end{array}$ & $\begin{array}{c}1.86 \\
(0.46)\end{array}$ \\
\hline
\end{tabular}

Note: Probit regression of selected indicators on 0/1 crisis dummy for six countries in 1981-1998. dProb/dx coefficients represent the change in the (0-100 percent) probability of a crisis caused by a one-unit change in the corresponding explanatory variable. $\mathrm{Z}$ statistics in parentheses. (L) indicates one-year lag. 


\section{Boiled-Down Regression Results}

Dependent Variable: Crisis Dummy

\begin{tabular}{lccc}
\hline & Kamin-Babson & Kaminsky-Reinhart & Import-based \\
\hline Chi $^{2}$ & 40.85 & 25.35 & 44.75 \\
Pseudo ${ }^{2}$ & 0.3251 & 0.2266 & 0.3754 \\
\hline Real GDP growth (L) & -3.38 & -1.36 & -0.96 \\
& $(-3.43)$ & $(-1.96)$ & $(-1.25)$ \\
Fiscal deficit/GDP (L) & & 0.91 & 2.17 \\
& & $(1.26)$ & $(2.69)$ \\
Loans/GDP (L) & & & -0.24 \\
& & & $(-2.18)$ \\
Real exchange rate (L) & & 0.32 &
\end{tabular}

Export growth (L)

Current account/GDP (L)

$-2.26$

$-4.67$

$(-2.09)$

International reserves/Imports (L)

M2/Reserves (L)

0.14

0.12

(2.83)

(2.12)

Total external debt/GDP (L)

0.43

(2.00)

Reserves/Short-term debt (L)

$-0.10$

$(-1.43)$

Change in terms of trade

$-0.70$

$-0.59$

$-0.69$

$(-1.68)$

$(-1.68)$

$(-1.72)$

Change in U.S. real interest rate

0.03

(1.40)

Industrial country GDP growth

Note: Probit regression of selected indicators on 0/1 crisis dummy for six countries in 1981-1998. dProb/dx coefficients represent the change in the (0-100 percent) probability of a crisis caused by a one-unit change in the corresponding explanatory variable. $\mathrm{Z}$ statistics in parentheses. (L) indicates one-year lag. 
Table 3

\section{Summary Indicators}

(Based on broad regressions)

\begin{tabular}{|c|c|c|c|c|}
\hline \multicolumn{5}{|c|}{ Kamin-Babson } \\
\hline & $(1)$ & (2) & (3) & (4) \\
\hline & $\begin{array}{c}\text { Avg. } \\
\text { probability of crisis } \\
\text { in crisis years }\end{array}$ & $\begin{array}{l}\text { Contribution of } \\
\text { domestic factors }\end{array}$ & $\begin{array}{l}\text { Contribution of } \\
\text { external balance } \\
\text { factors }\end{array}$ & $\begin{array}{c}\text { Contribution } \\
\text { of external shocks }\end{array}$ \\
\hline Argentina & 0.586 & 0.445 & 0.109 & 0.033 \\
\hline Brazil & 0.421 & 0.513 & 0.061 & -0.153 \\
\hline Chile & 0.747 & 0.357 & 0.161 & 0.229 \\
\hline Colombia & 0.483 & 0.374 & 0.214 & -0.105 \\
\hline Mexico & 0.465 & 0.149 & 0.155 & 0.161 \\
\hline Venezuela & 0.535 & 0.493 & 0.099 & -0.057 \\
\hline Average & 0.539 & 0.388 & 0.133 & 0.018 \\
\hline \multicolumn{5}{|c|}{ Kaminsky-Reinhart } \\
\hline & $(1)$ & $(2)$ & (3) & $(4)$ \\
\hline & $\begin{array}{c}\text { Avg. } \\
\text { probability of crisis } \\
\text { in crisis years }\end{array}$ & $\begin{array}{l}\text { Contribution of } \\
\text { domestic factors }\end{array}$ & $\begin{array}{l}\text { Contribution of } \\
\text { external balance } \\
\text { factors }\end{array}$ & $\begin{array}{c}\text { Contribution } \\
\text { of external shocks }\end{array}$ \\
\hline Argentina & 0.627 & 0.517 & 0.064 & 0.046 \\
\hline Brazil & 0.233 & 0.331 & -0.020 & -0.077 \\
\hline Chile & 0.395 & 0.157 & 0.066 & 0.172 \\
\hline Colombia & 0.353 & 0.391 & 0.258 & -0.295 \\
\hline Mexico & 0.440 & 0.377 & 0.008 & 0.055 \\
\hline Venezuela & 0.239 & 0.185 & 0.126 & -0.072 \\
\hline Average & 0.381 & 0.326 & 0.084 & -0.029 \\
\hline \multicolumn{5}{|c|}{ Import-based } \\
\hline & $(1)$ & (2) & (3) & (4) \\
\hline & $\begin{array}{c}\text { Avg. } \\
\text { probability of crisis } \\
\text { in crisis years }\end{array}$ & $\begin{array}{l}\text { Contribution of } \\
\text { domestic factors }\end{array}$ & $\begin{array}{l}\text { Contribution of } \\
\text { external balance } \\
\text { factors }\end{array}$ & $\begin{array}{c}\text { Contribution } \\
\text { of external shocks }\end{array}$ \\
\hline Argentina & 0.674 & 0.550 & 0.028 & 0.096 \\
\hline Brazil & 0.472 & 0.348 & 0.218 & -0.093 \\
\hline Chile & 0.541 & 0.173 & 0.363 & 0.005 \\
\hline Colombia & 0.623 & 0.392 & 0.189 & 0.042 \\
\hline Mexico & 0.712 & 0.382 & 0.096 & 0.234 \\
\hline Venezuela & 0.479 & 0.157 & 0.557 & -0.234 \\
\hline Average & 0.584 & 0.334 & 0.242 & 0.008 \\
\hline
\end{tabular}


Chart 1a

\section{Argentina}

Broad
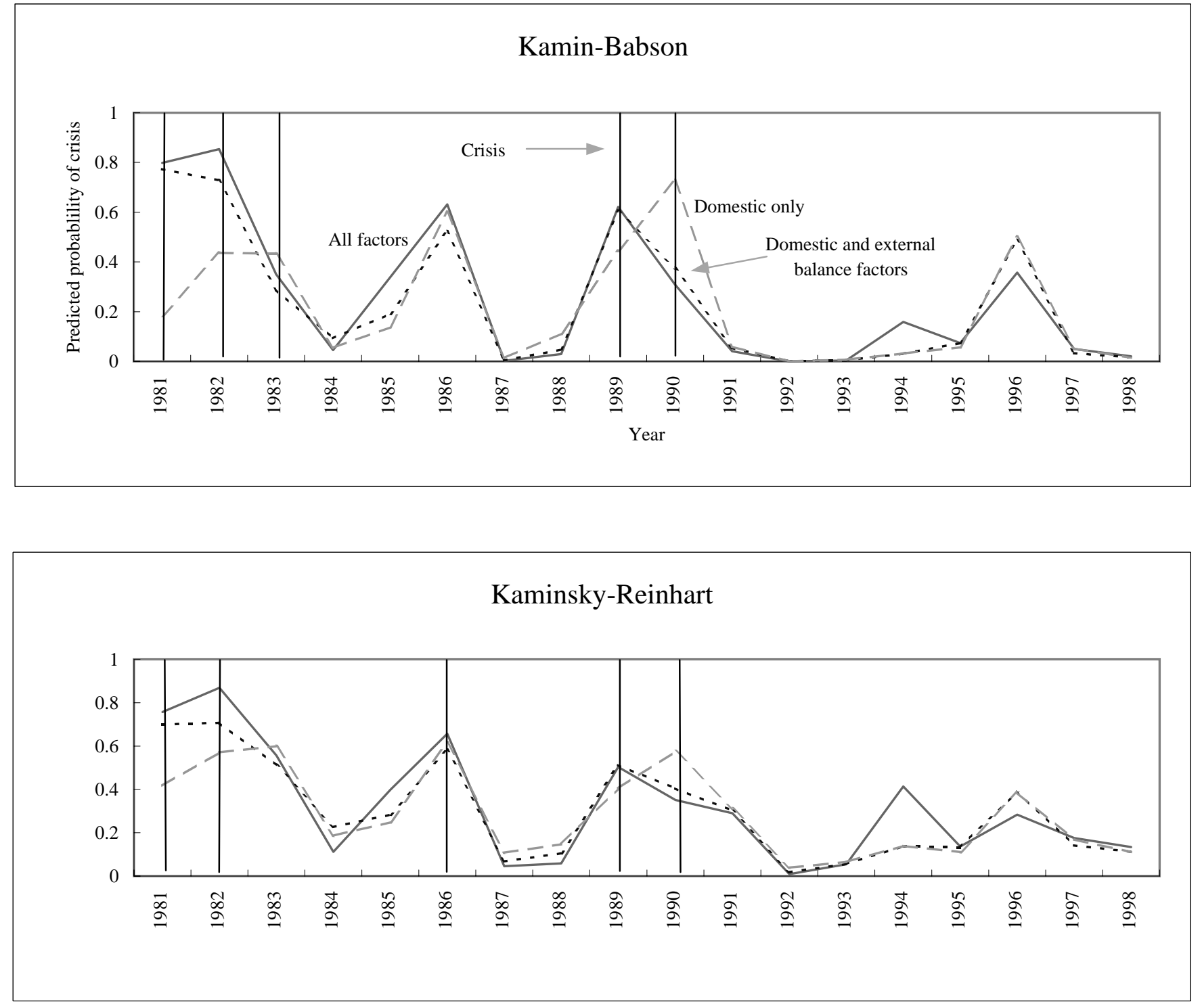

\section{Import-based}

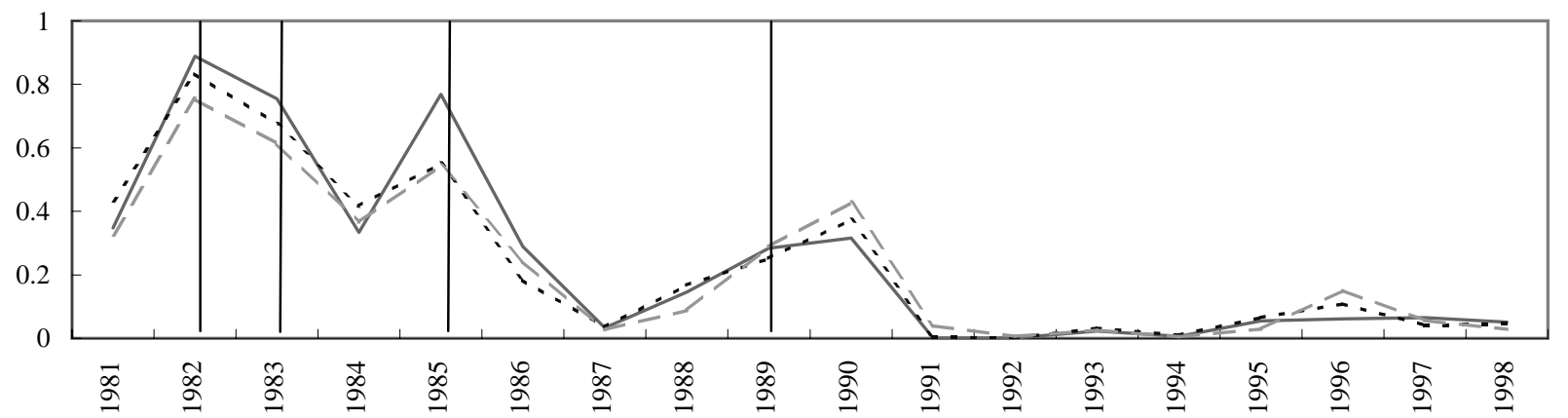


Chart $1 \mathrm{~b}$

\section{Brazil}

Broad
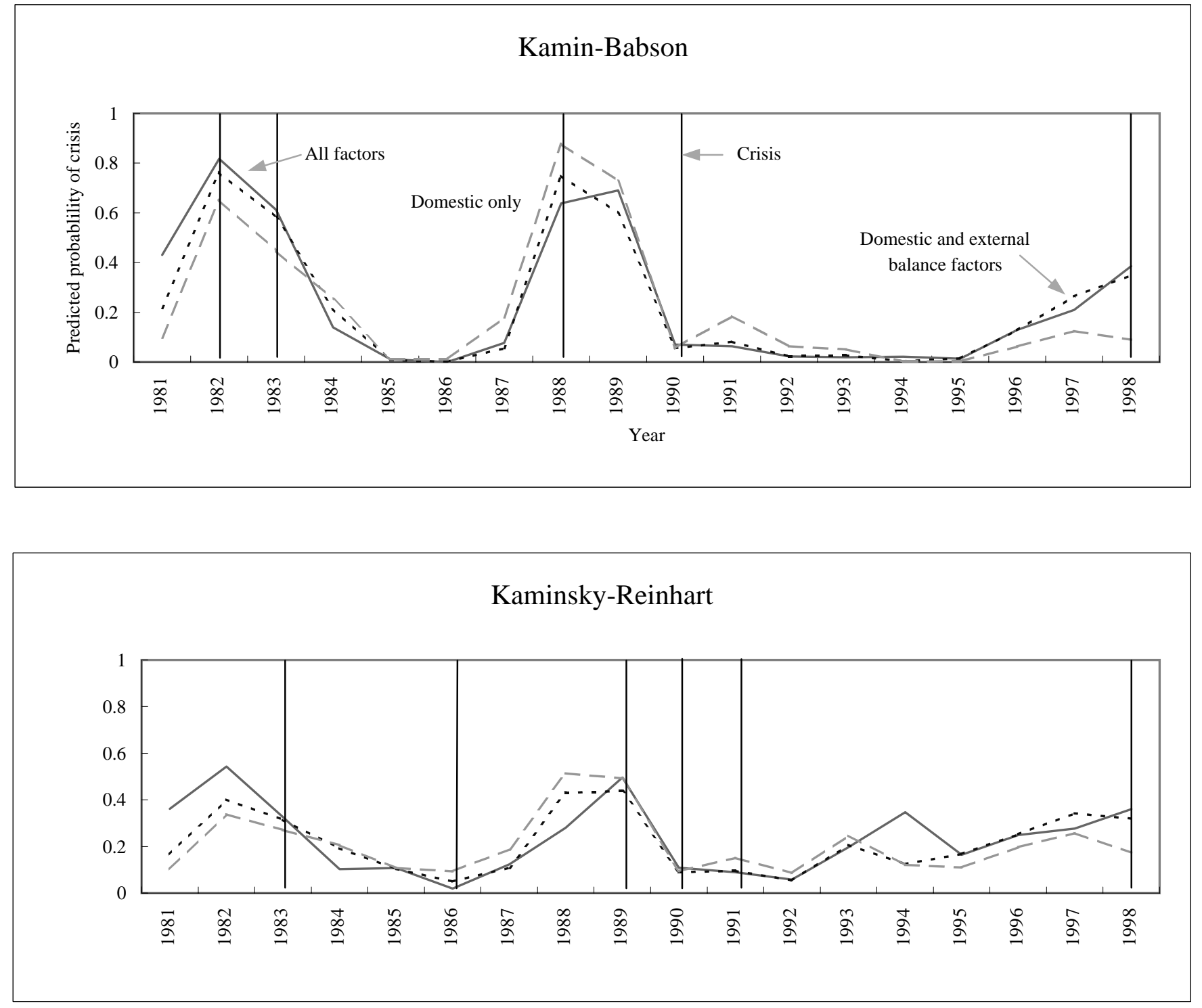

\section{Import-based}

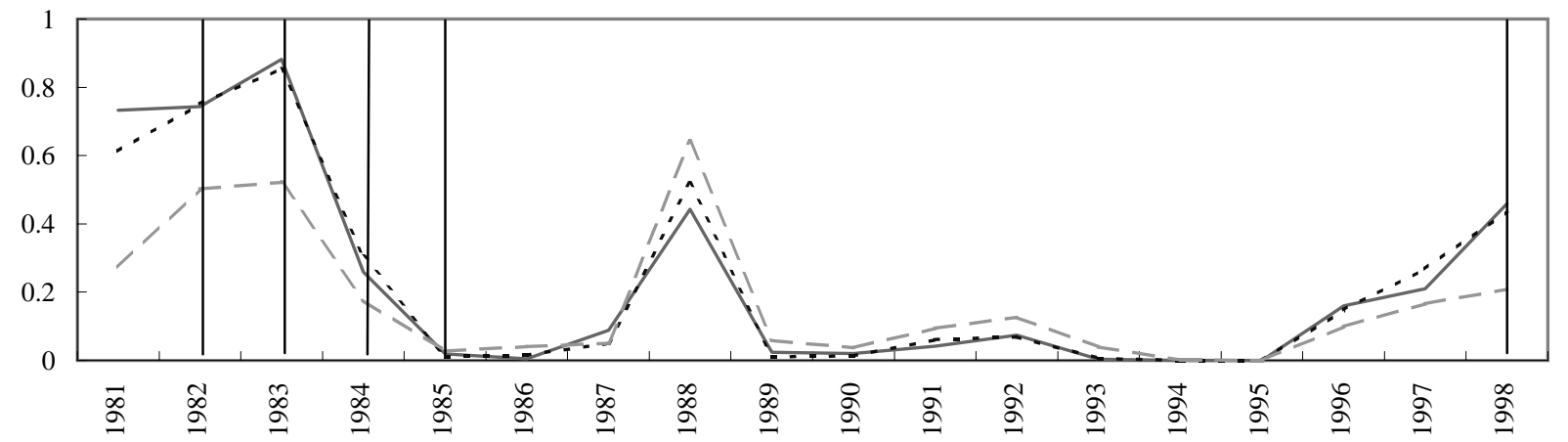


Chart 1c

\section{Chile}

Broad
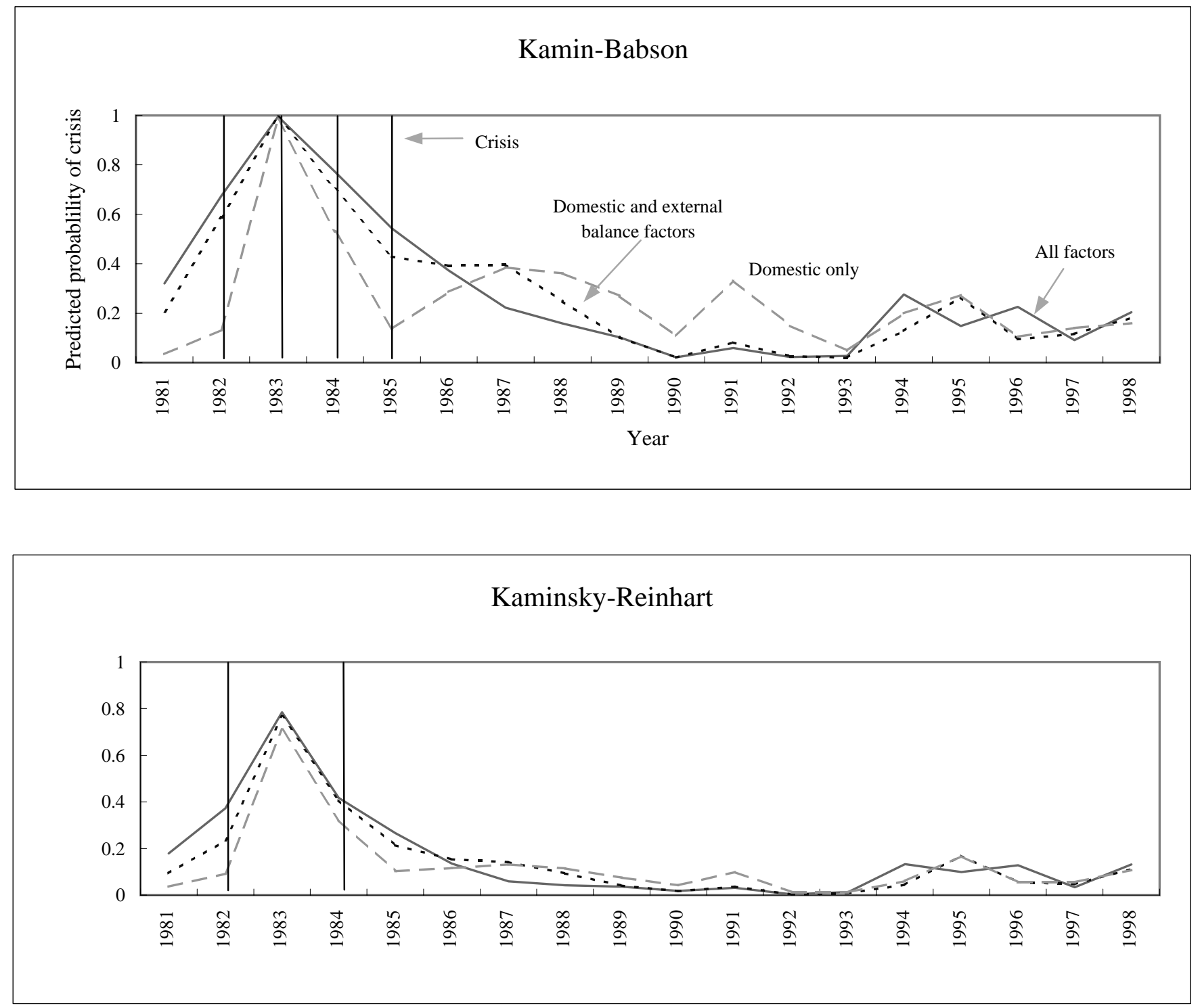

\section{Import-based}

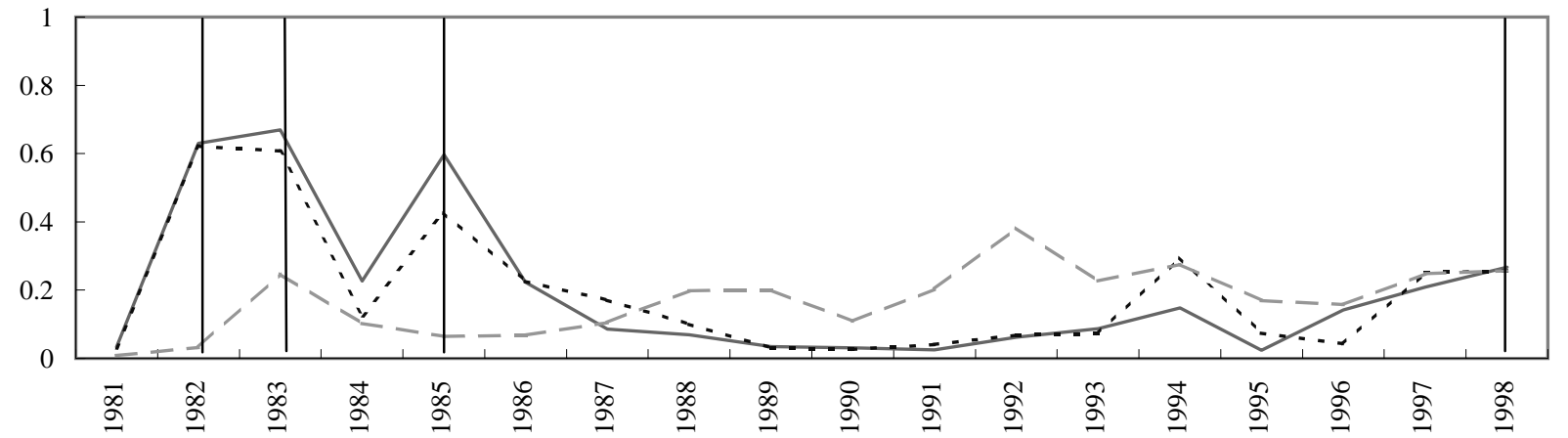


Chart 1d

\section{Colombia}

Broad
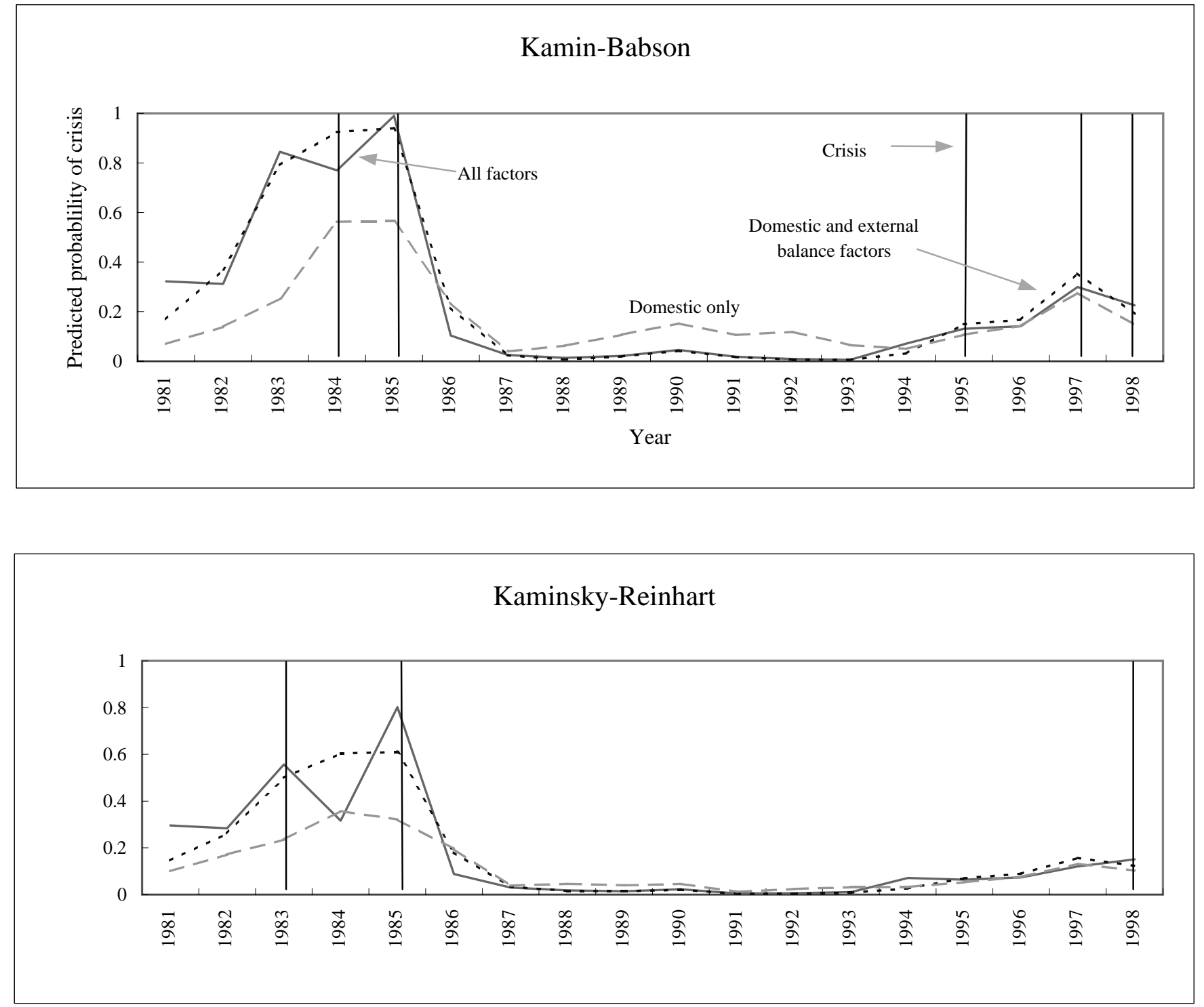

\section{Import-based}

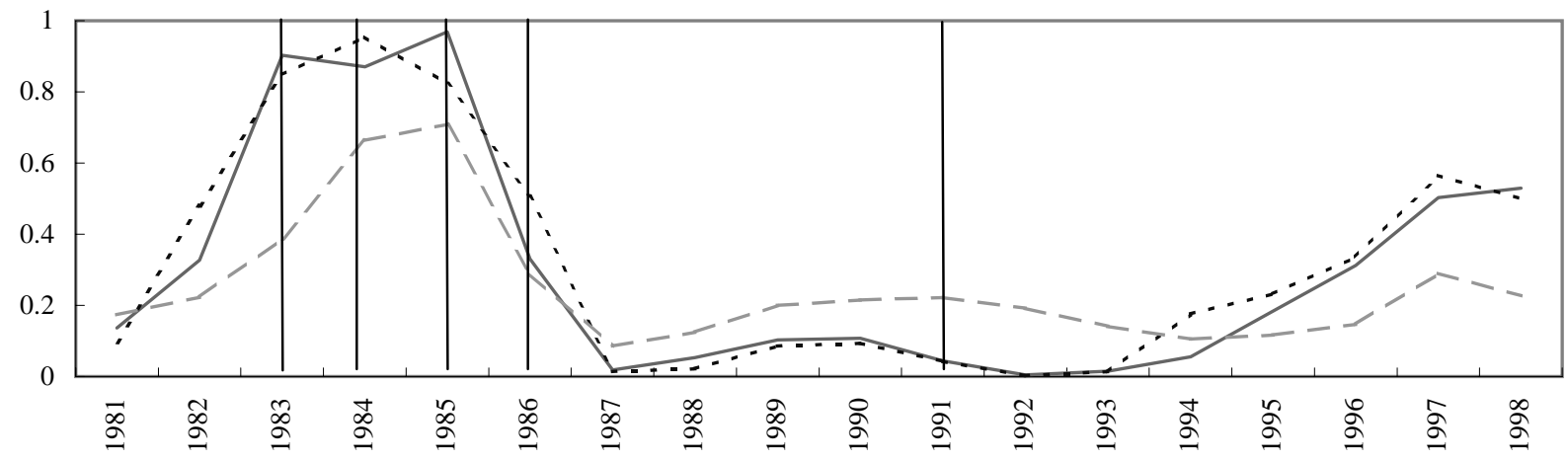


Chart 1e

\section{Mexico}

Broad
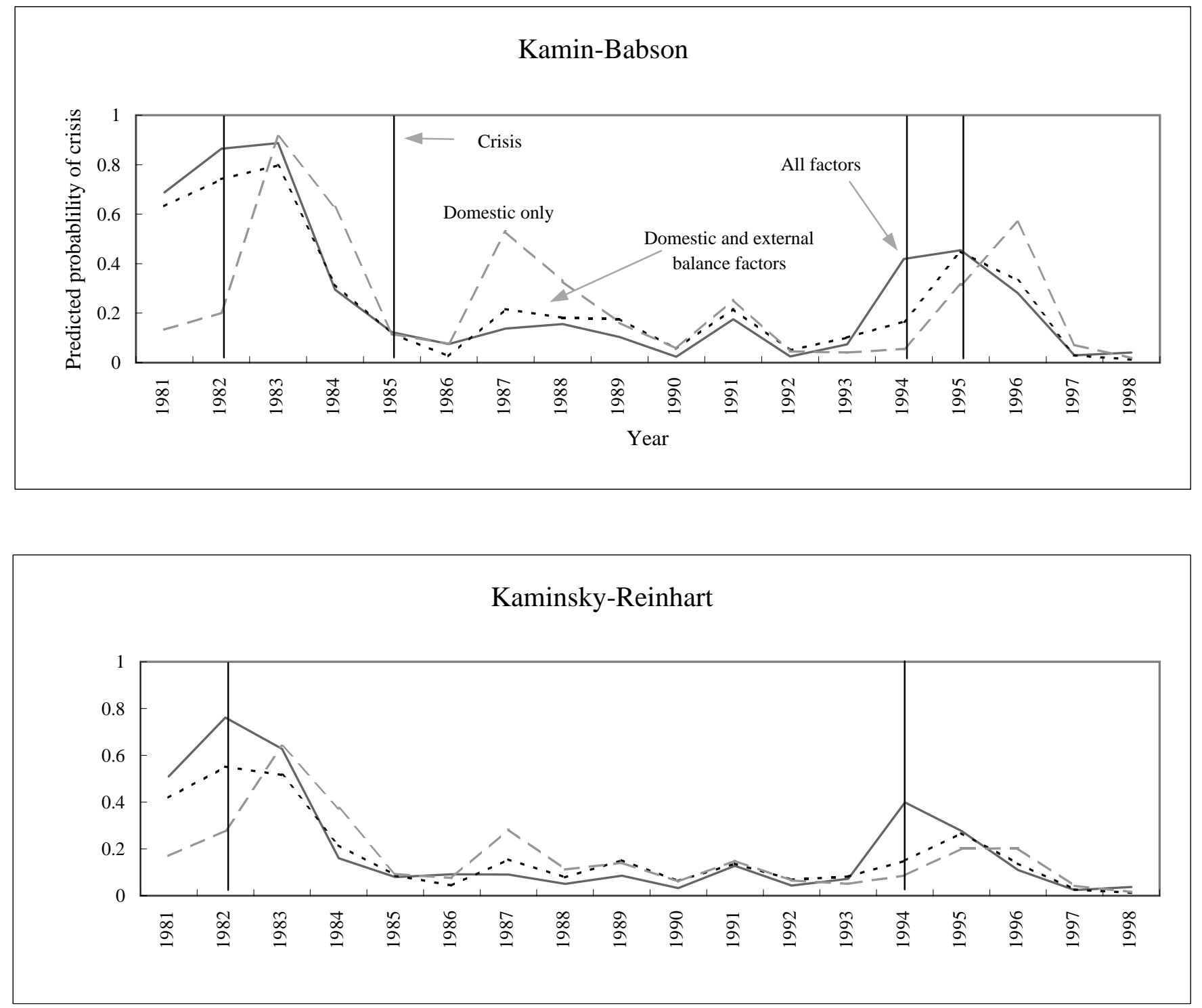

\section{Import-based}

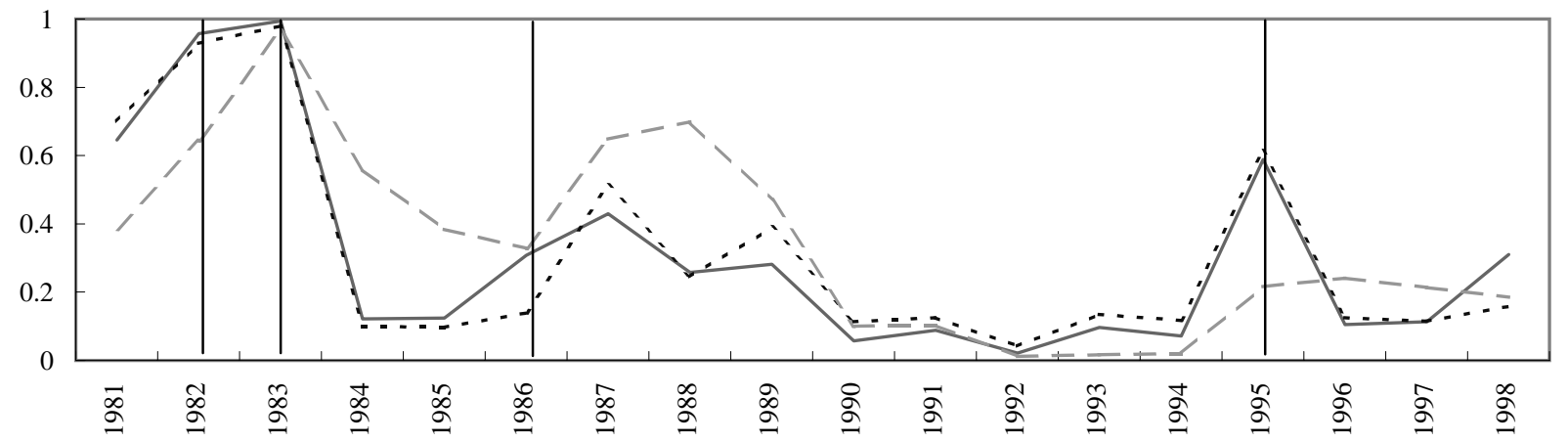


Chart $1 f$

\section{Venezuela}

Broad
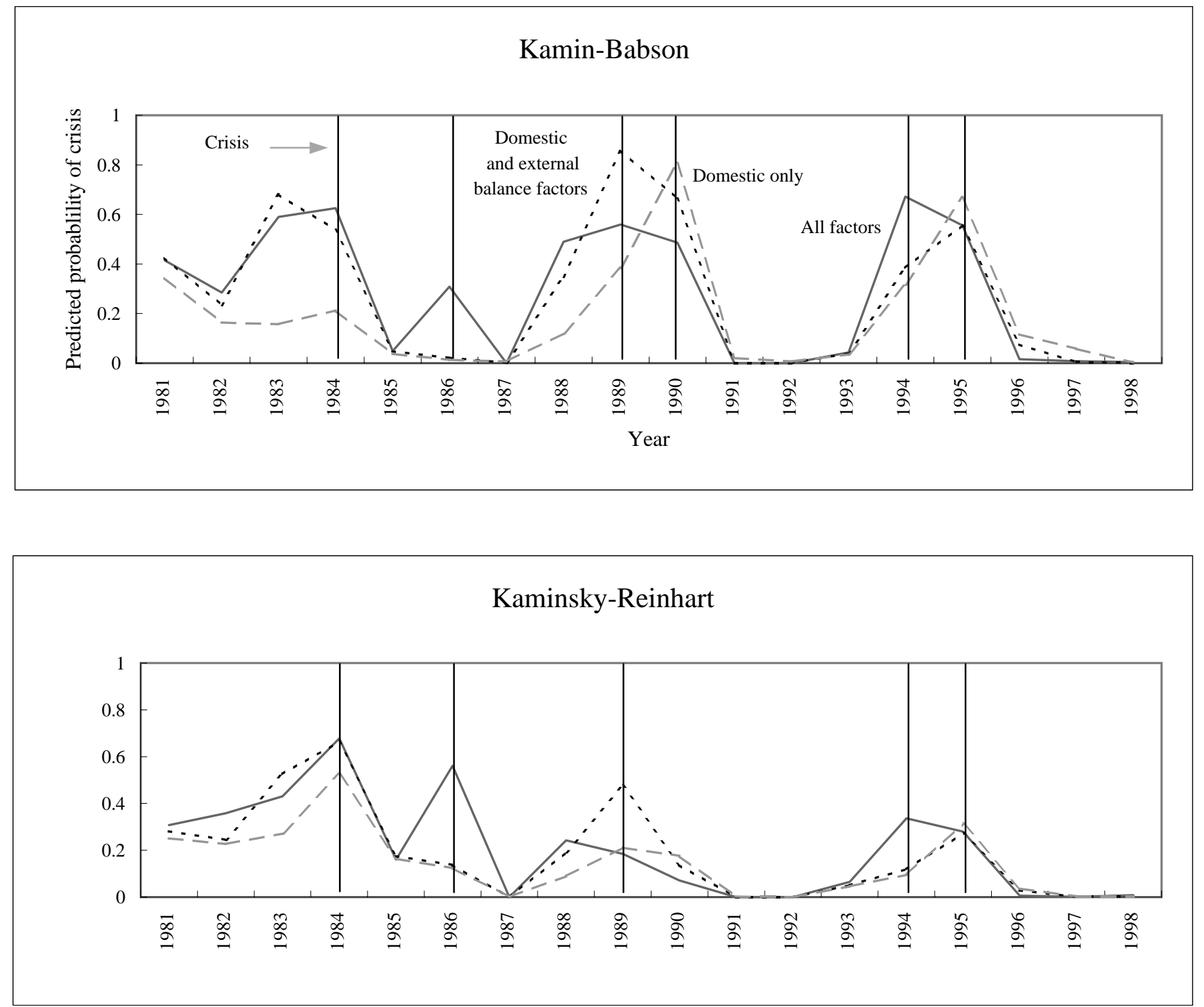

\section{Import-based}

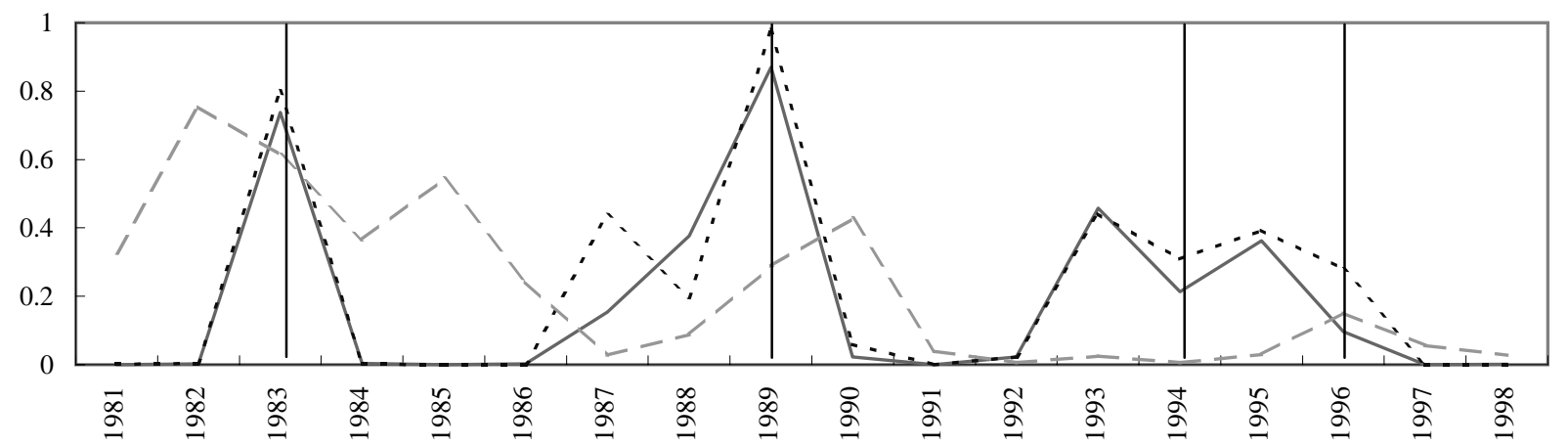




\section{Argentina}

Boiled-down
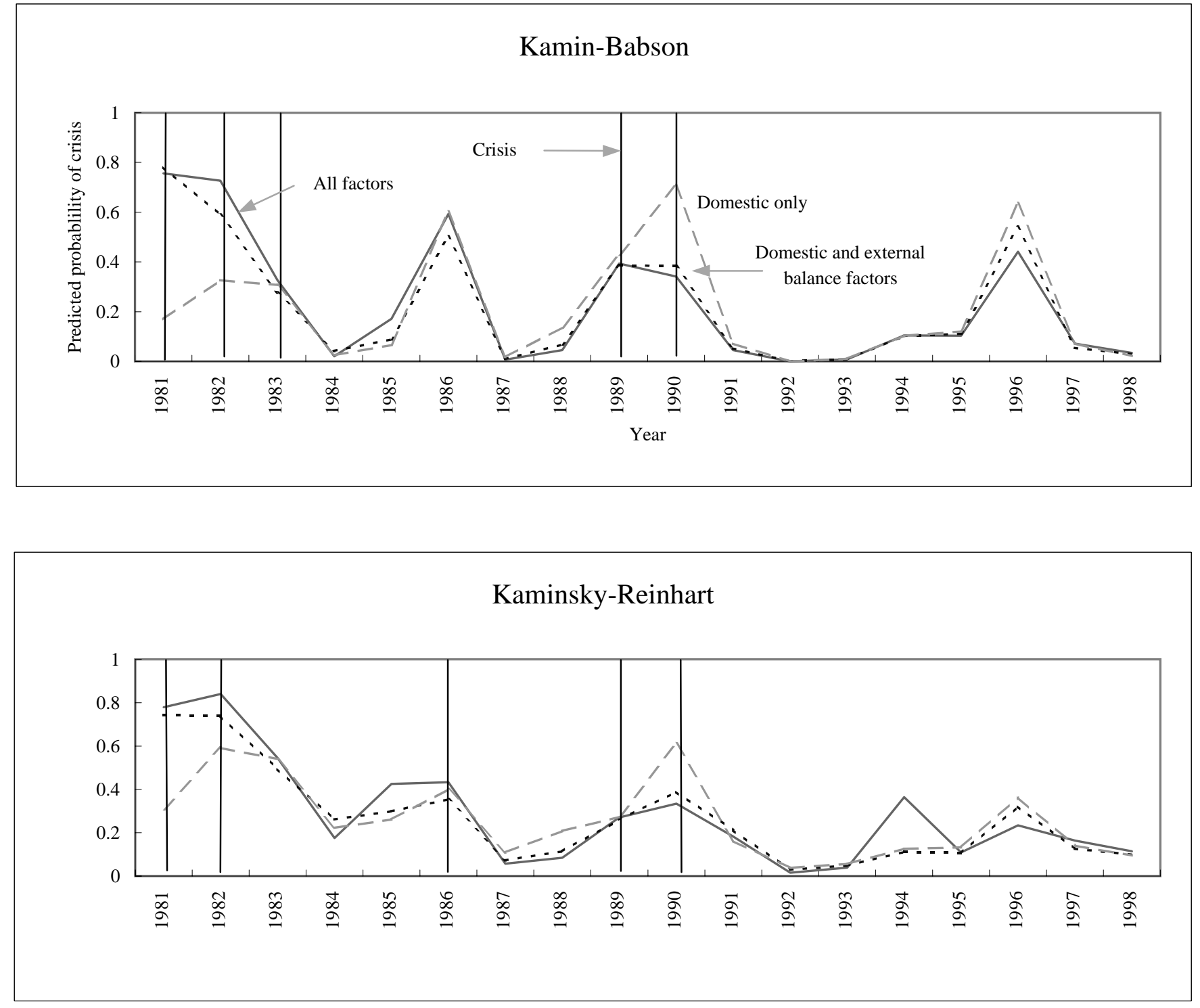

\section{Import-based}

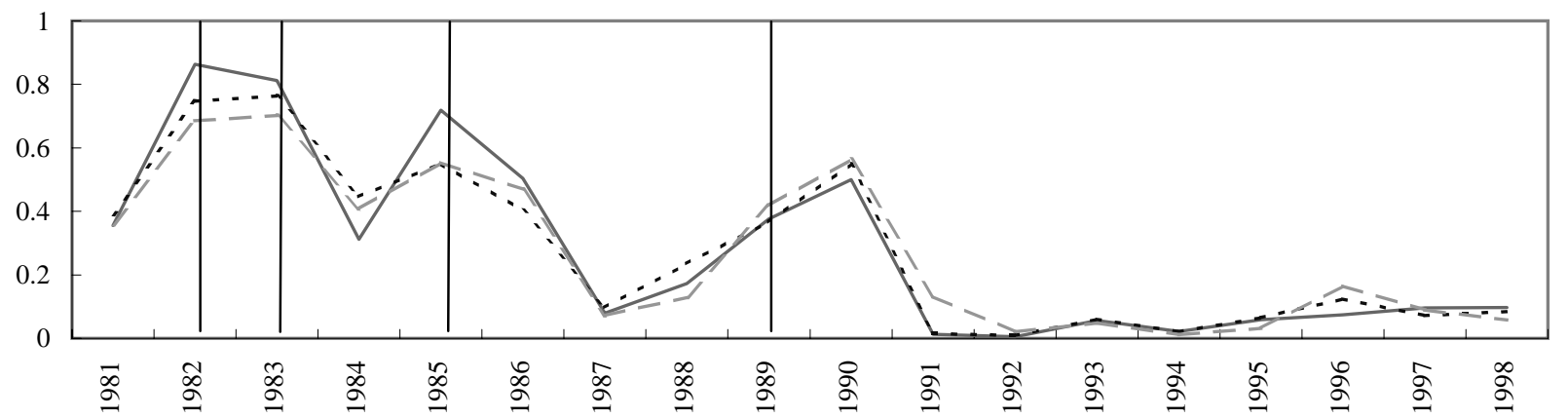


Chart $2 b$

\section{Brazil}

Boiled-down
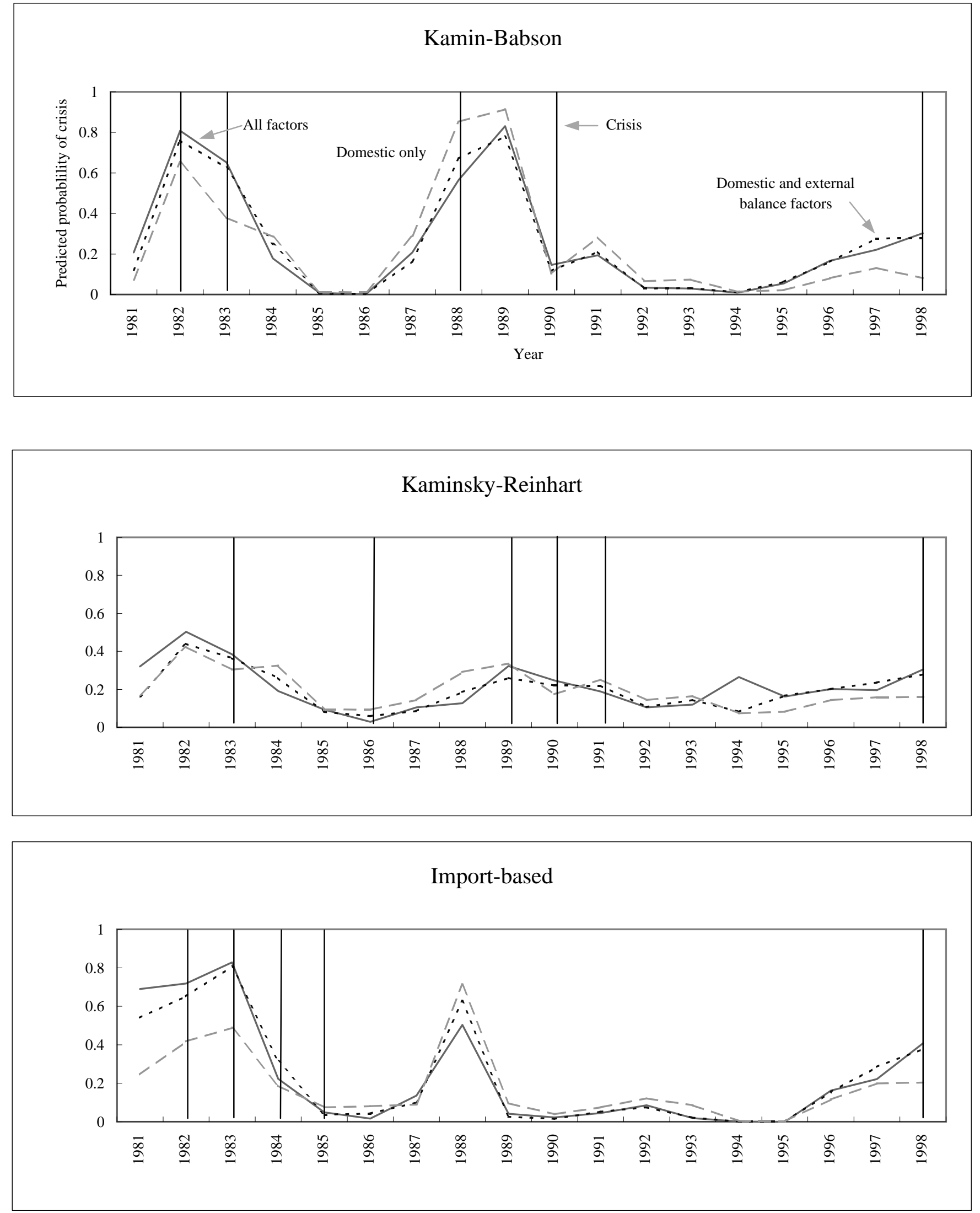
Chart 2c

\section{Chile}

Boiled-down
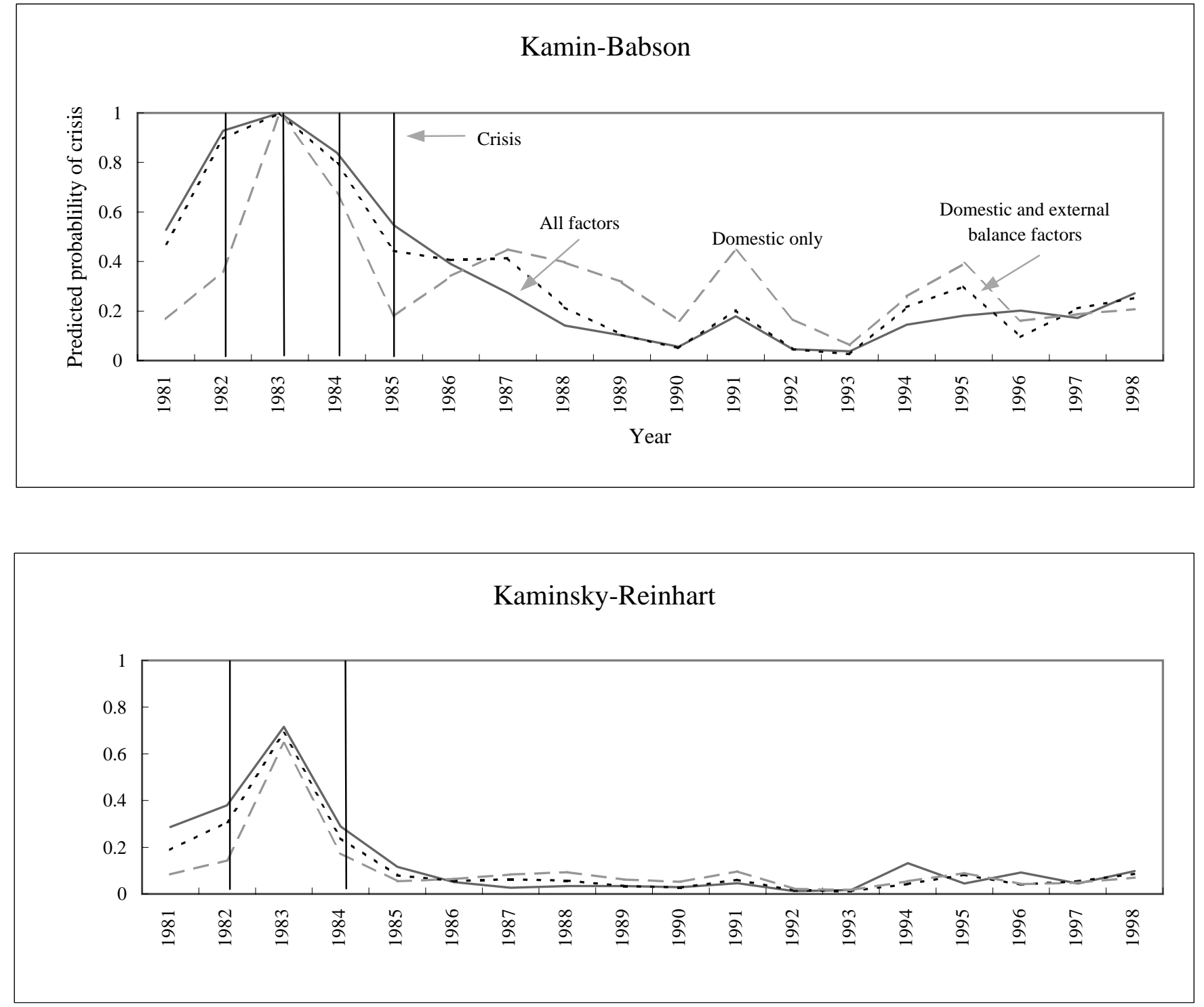

\section{Import-based}

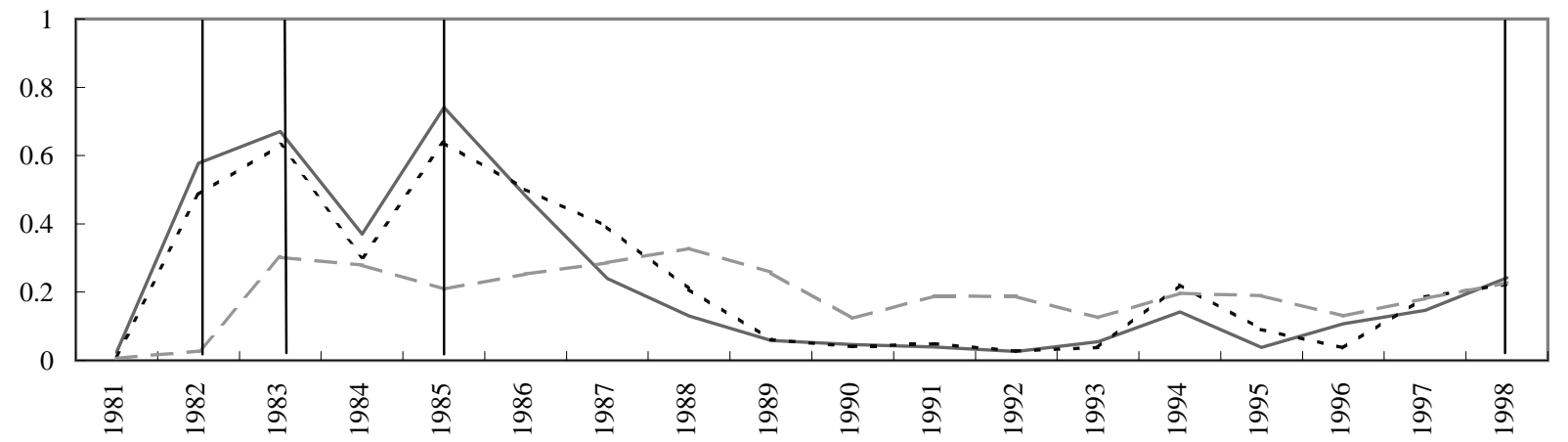


Chart 2d

\section{Colombia}

Boiled-down
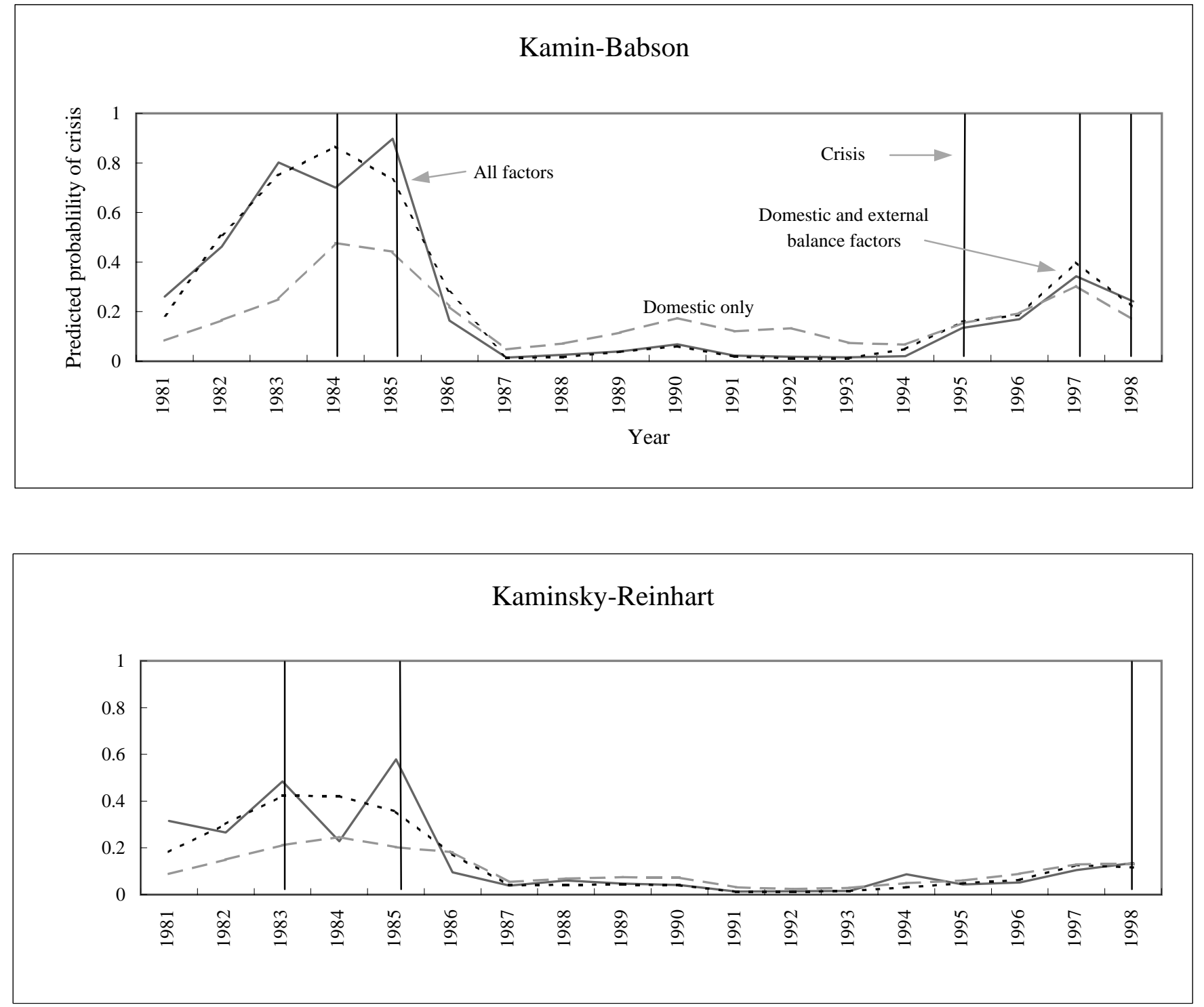

\section{Import-based}

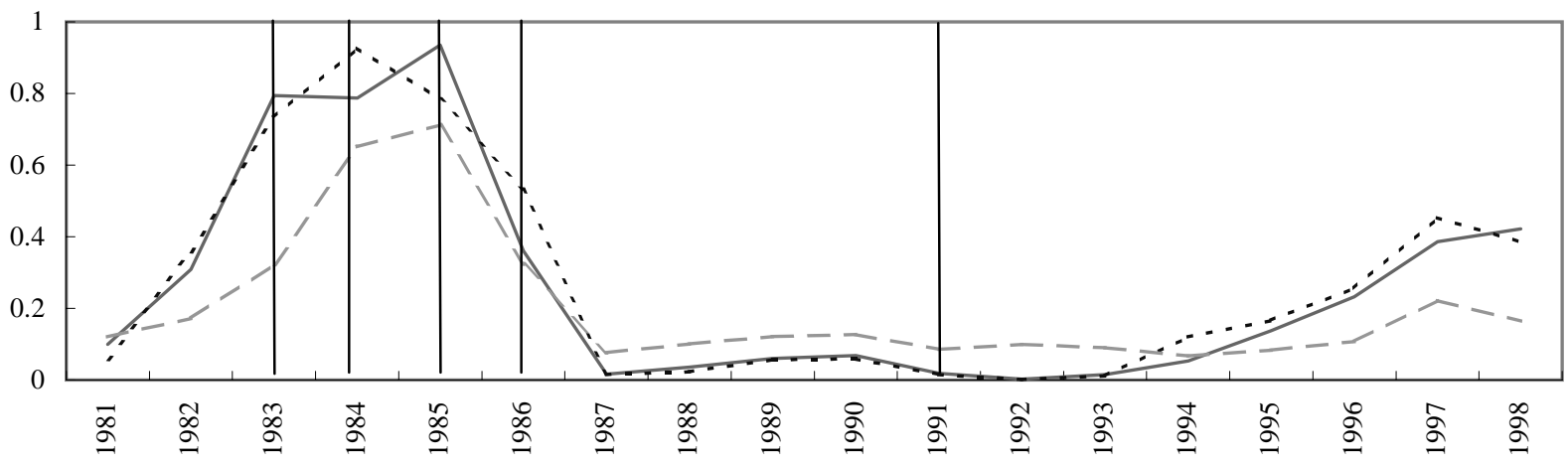


Chart 2e

\section{Mexico}

Boiled-down
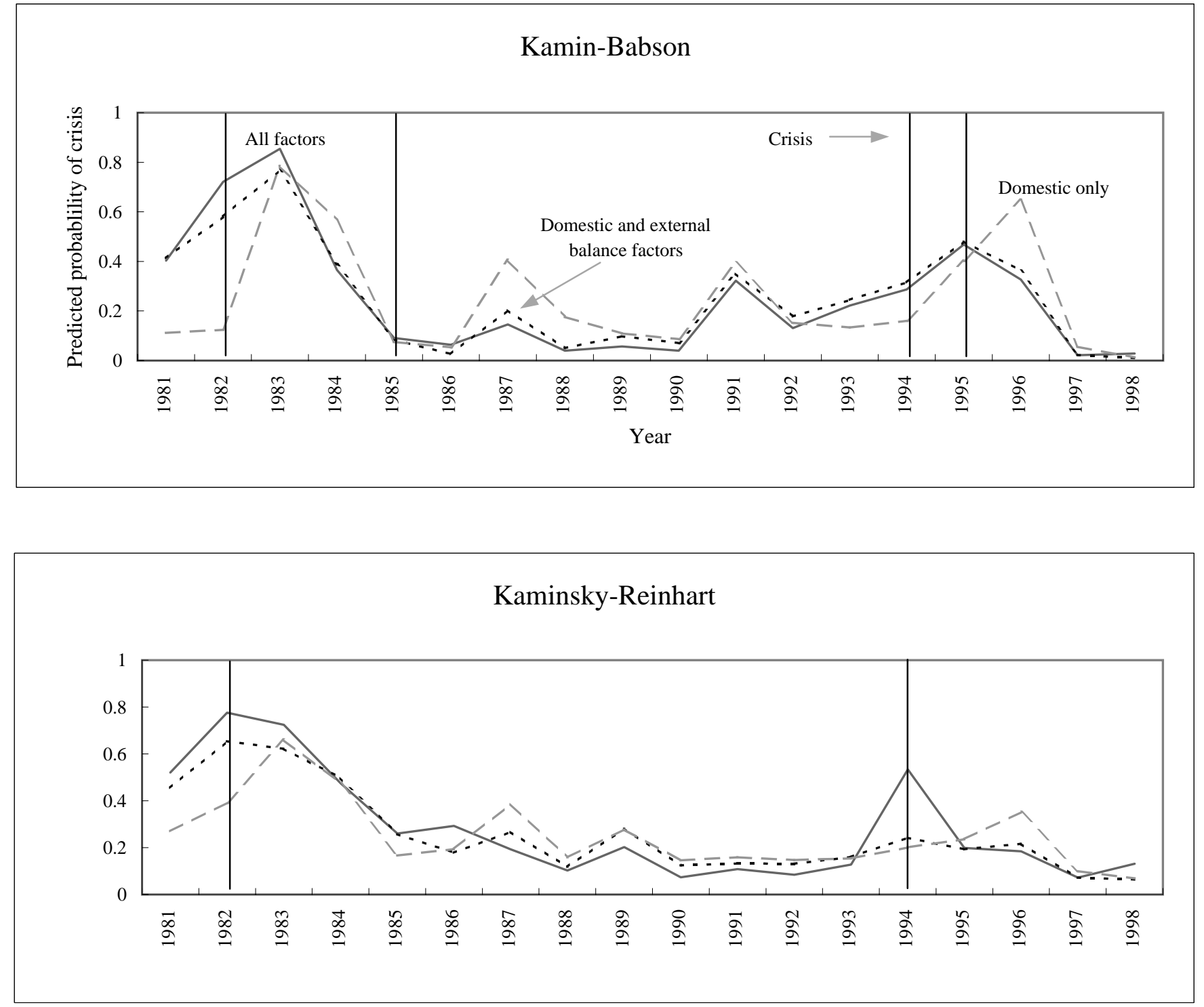

\section{Import-based}

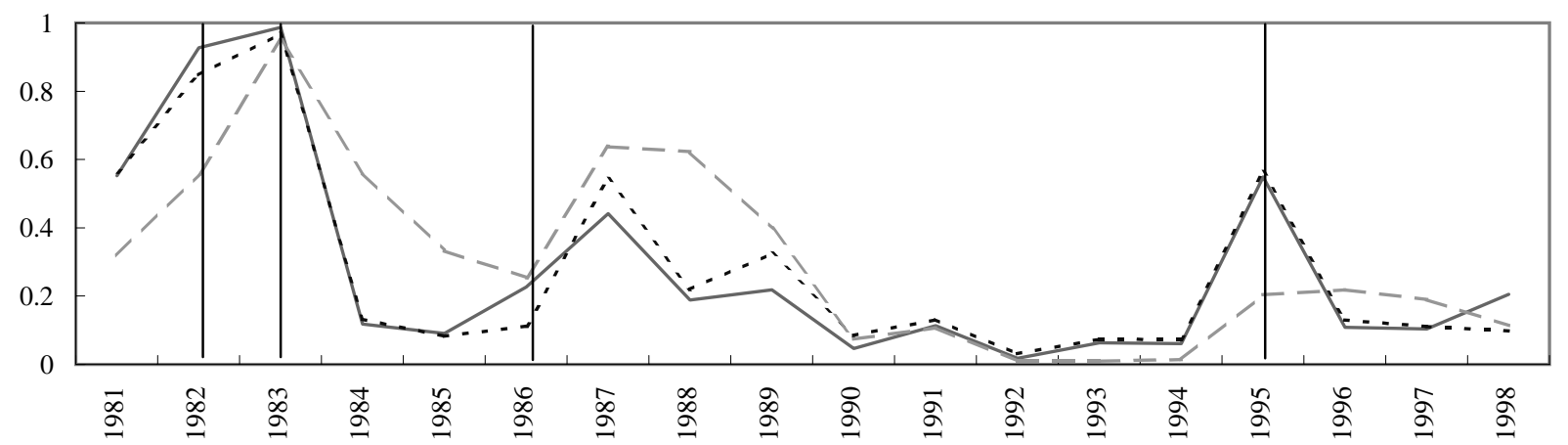




\section{Venezuela}

Boiled-down
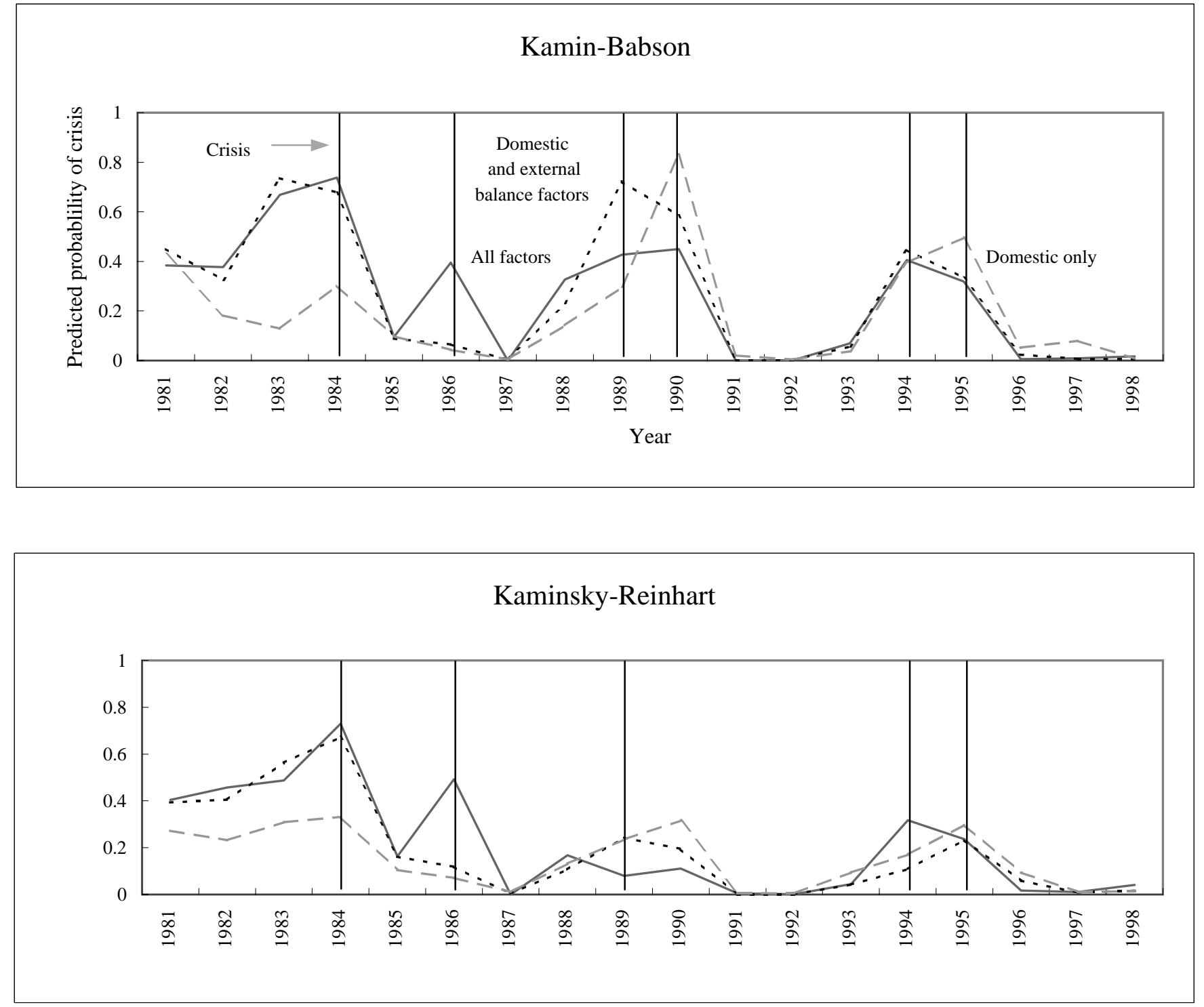

\section{Import-based}

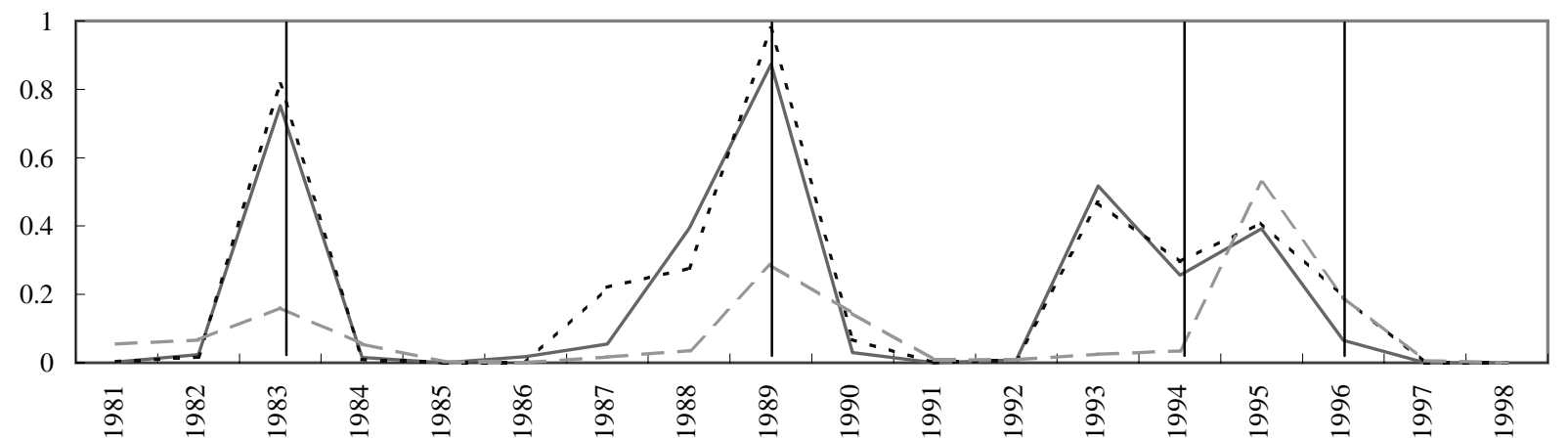


Appendix Table 1

\section{Definitions of "Troublespot" Indicators}

(1) Growth of Real GDP

$$
\% \Delta \mathrm{GDP}_{\mathrm{t}}-\frac{\left(\% \Delta \mathrm{GDP}_{\mathrm{t}-1}+\% \Delta \mathrm{GDP}_{\mathrm{t}-2}+\% \Delta \mathrm{GDP}_{\mathrm{t}-3}\right)}{3}
$$

(2) Public Sector Deficit

$$
\frac{\text { Public Sector Deficit }}{\text { GDP }} \times 100
$$

(Note: “_“ denotes a surplus)

(3) Domestic Bank Loans

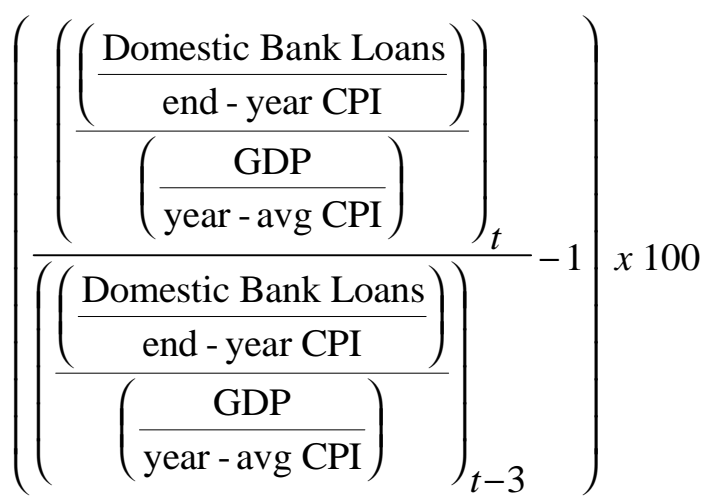

(4) Real Effective Exchange Rate

$$
\left(\left(\frac{\text { REER }_{\mathrm{t}}}{\left(\frac{\mathrm{REER}_{1980-1997}}{18}\right)}\right)-1\right) x 100
$$


(5) Exports

$$
\% \Delta \text { Exports }_{\mathrm{t}}-\frac{\left(\% \Delta \text { Exports }_{\mathrm{t}-1}+\% \Delta \text { Exports }_{\mathrm{t}-2}+\% \Delta \text { Exports }_{\mathrm{t}-3}\right)}{3}
$$

(6) Current Account

$$
\frac{\text { Current Account }}{\text { \$GDP }} \times 100
$$

(7) International Reserves

$$
\frac{\text { Total Reserves Less Gold }}{\text { Imports }} x 100
$$

(8) M2 Money Supply

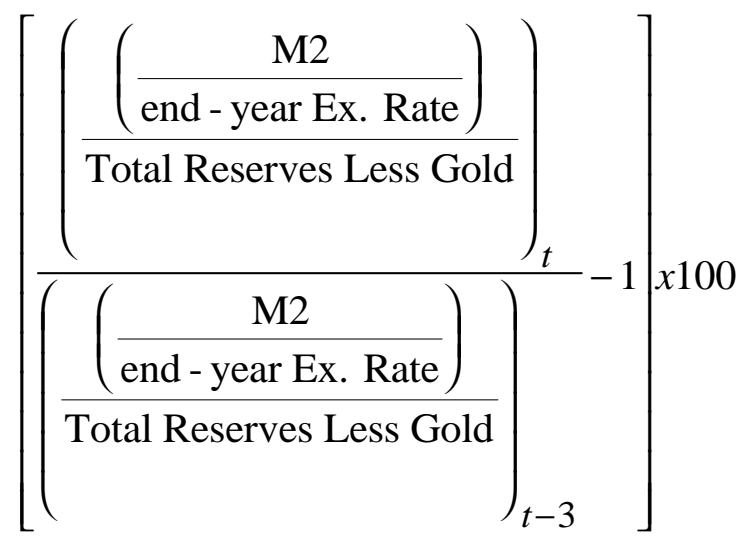

(9) Total External Debt

$$
\frac{\text { Total External Debt }}{\text { GDP }} \times 100
$$

(10) Short-term Debt

$$
\frac{\text { Total Reserves Less Gold }}{\text { Short - term Debt }} x 100
$$


(11) Terms of Trade

$$
\left(\frac{\text { Terms of Trade }_{t}}{{\text { Terms of } \text { Trade }_{t-1}}}-1\right) x 100
$$

(12) U.S. Real Interest Rate

$\left(\frac{\text { Avg. Annual U.S. } 3 \text { - month Interest Rate }{ }_{t}-\text { Annual Avg. CPI Inflation }_{t}}{\text { Avg. Annual U.S. } 3 \text { - month Interest Rate } \text { R }_{t-1}-\text { Annual Avg. CPI Inflation }_{t-1}}-1\right) x 100$

(Note: To calculate percentage change, 1980 level was arbitrarily set to 2 percent, since its actual value was negative.)

(13) Industrial Country GDP Growth

Real Annual Average Growth 